Article

\title{
Sustainable Construction for Urban Infill Development Using Engineered Massive Wood Panel Systems
}

\section{Steffen Lehmann}

The University of South Australia, GPO Box 2471, Adelaide SA 5001, Australia; E-Mail: steffen.lehmann@unisa.edu.au; Tel.: +61-8-8302-0654; Fax: +61-8-8302-0211.

Received: 13 August 2012; in revised form: 1 October 2012 / Accepted: 4 October 2012; Published: 18 October 2012

\begin{abstract}
Prefabricated engineered solid wood panel construction systems can sequester and store $\mathrm{CO}_{2}$. Modular cross-laminated timber (CLT, also called cross-lam) panels form the basis of low-carbon, engineered construction systems using solid wood panels that can be used to build residential infill developments of 10 storeys or higher. Multi-apartment buildings of 4 to 10 storeys constructed entirely in timber, such as recently in Europe, are innovative, but their social and cultural acceptance in Australia and North America is at this stage still uncertain. Future commercial utilisation is only possible if there is a user acceptance. The author is part of a research team that aims to study two problems: first models of urban infill; then focus on how the use of the CLT systems can play an important role in facilitating a more livable city with better models of infill housing. Wood is an important contemporary building resource due to its low embodied energy and unique attributes. The potential of prefabricated engineered solid wood panel systems, such as CLT, as a sustainable building material and system is only just being realised around the globe. Since timber is one of the few materials that has the capacity to store carbon in large quantities over a long period of time, solid wood panel construction offers the opportunity of carbon engineering, to turn buildings into 'carbon sinks'. Thus some of the historically negative environmental impact of urban development and construction can be turned around with CLT construction on brownfield sites.
\end{abstract}

Keywords: engineered timber; prefabrication; solid wood panel construction system; social acceptance; sustainable design 


\section{Introduction and Problem Definition}

Scientists are increasingly able to present empirical evidence about the environmental impact of global warming, including rising temperatures, soil erosion, and deforestation, falling water tables, ice melting, loss of biodiversity and animal habitat, threats to food security and the questionable use of grain to produce fuel for cars. Bold changes are needed to reduce carbon emissions; global warming also forces us to rethink the way we deal with population growth, urban development, carbon- and energy-intensive construction systems, linear and unsustainable material flows, consumption and urban life in general.

Most cities in the Asia-Pacific region are grappling with the challenges of urbanization and population growth. Alongside the concept of the 'sustainable city', the notion of the 'liveable city' has gained attention. The 'sustainable city' and the 'liveable city' are measured differently (for instance, a very energy-efficient city could still be an awful place to live). On the other hand, Australian cities are usually very liveable but not sustainable. So a step-by-step transformation of cities is required to increase their sustainability and peak oil resilience [1]. There is scientific evidence that larger cities use resources more efficiently than smaller cities because of economy of scale; and that denser and well-interconnected cities generate less carbon per person [2-6].

As Australian cities grow inwards and become more compact, the cultural and social acceptance of urban infill and inner-city living becomes an issue. Urban infill and developments on brownfield sites mean cities become denser, so that residents can live in proximity to public transport, mixed-use precincts and their workplaces; it involves people moving from suburbs back to city centres and accepting multi-storey apartment buildings and townhouses. But therefore better models of infill housing are needed to ensure acceptance of inner-city living. An unattractive, overdeveloped example of inner-city apartment living in Sydney is shown in Figure 1.

Our linear economic system and current models of urbanization are based on the notion of continual urban and industrial growth, ever-expanding consumption, disposable products, resource depletion, waste creation and pollution [7-8]. Resources are extracted from the earth, refined, manufactured into parts and assembled into products, which are widely distributed, sold, used, discarded, disposed and replaced. Walker (2006) notes that 'this system's flow of resources and energy is linear and unidirectional: most of it is not recyclable, ending up in landfill' [9]. Repair, re-use, refurbishment and retrieval (recovery) of resources, materials and building components do not yet feature in this system; construction systems that allow 100 percent recyclability, or disassembly and re-use of entire components, would be far better.

Architects and planners are now looking for new, responsible ways of living in cities and better inner-city housing models, to attract people back from suburbs to the centres. It is clear that things are changing and we must make every effort to future-proof the built environment by designing more resilient urban systems and more compact urban housing. The technology for energy generation and supply is transforming quickly, while the construction sector is still working out the ramifications of climate change and possible responses. However, the transition from fossil fuels to renewable sources of energy is moving much faster than most people realize, notes environmentalist Lester Brown (2009) [10]; while a mostly conservative and therefore slow-to-change construction sector has yet to fully embrace principles of ethical consumption, low carbon construction and waste reduction. 
Housing construction is of exceptional significance as a driver of the Australian economy and a fundamental social need. A report by FWPA (2012) [11] states that 'the areas of design, material technology and construction process management in housing, have significant potential for improvement through emerging technologies, but to date, the Australian construction industry has been slow to adopt new technologies relative to other advanced countries'.

Figure 1. Typical inner-city apartment buildings developed for Sydney or Melbourne in the last decade are frequently unpopular: they are unaffordable, lack privacy, have poor acoustic qualities and low ceilings (usually the minimum floor-to-floor height of $2.4 \mathrm{~m}$ ), hence they are derogatorily referred to as 'chicken coops'.

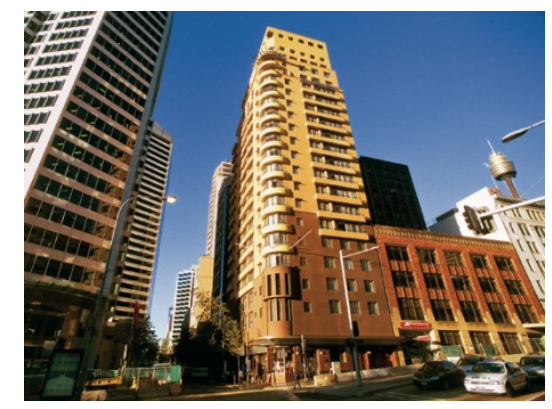

\subsection{Better Inner-City Housing Models for Urban Infill}

Australian and North American cities in particular will need to be transformed towards higher densities and a more compact urban form using infill to reduce their car dependency, high greenhouse gas emissions and land consumption [1,3]. Unsustainable 'functional city' models evolved during the automobile era, in a time of cheap fossil fuels. Today, the ratio of parks to parking lots has become a solid indicator of the liveability of a city - an indication of whether the city is designed for people or for cars. While cars promise mobility (and in a largely rural setting they can provide it), there is now an inherent conflict between automobiles and the liveability of a city [12]. Increasing travel costs (due to rising oil prices) will have the most effect on people living in outer suburbs, especially the elderly who often live isolated in suburban areas without efficient public transport. Worldwide, planners are reconsidering the urban role of automobiles and redesigning inner-city communities so that public transportation is the centrepiece of mobility and streets are more pedestrian and bicycle friendly. Good examples of such green districts with compact urban form and mix of housing types, developed as urban infill on brownfield sites, are Vauban-Freiburg (Germany), Hammarby-Stockholm (Sweden) and Malmo Waterfront (Sweden), and the urban revitalization of Berlin and Barcelona.

In Australia we urgently need better, more liveable and affordable models of inner-city housing as urban infill on brownfield sites [13-14]. If this were combined with low-carbon prefabricated construction systems, developers could deliver infill developments more rapidly and affordable, without unpleasant noise for neighbours. The lack of storage space for construction components and materials on inner-city sites would not matter, as prefabricated elements would be produced off-site and delivered to sites just in time for assembly. 
The other emerging topic is behaviour change. Our values and behaviours define the way we aspire to live. Changing behaviour in regard to inner-city living and consumption patterns is likely to deliver significant improvements, helping to curb the threat of environmental degradation and global warming [15-17].

Most people make careful decisions before committing large sums of money to housing. However, understanding why consumers make decisions requires research and the collection of qualitative data. Major demographic shifts are underway, specifically a growth in smaller households and an ageing population, leading to particular housing needs. As a consequence, there are significant changes happening in the way we will live, and imagine ourselves living. For instance, the Grattan Institute's recent report The Housing We Would Choose (2011) [18] found that the importance of living with a garden and backyard has recently slipped from second to 23rd place, while living close to work and access to public transport are now most important for Australians. Other recent research by the Grattan Institute on Australians' housing preferences has shown that a desirable inner-city location has now the most influence on residential choices, while experiencing a sense of community has grown in importance.

Thus urban densification and infill housing have become established features of modern urban design policy in Australia [19]. Furthermore, the Grattan Institute report (2011) [18] reveals that Australians would like to be able to choose between a much more varied mixes of housing types than currently provided. The lack of affordable inner-city housing in buildings higher than 4 storeys was frequently mentioned as an issue.

Maliene and Malys [20] have proposed a model to aid sustainable housing developments in the UK based on characteristics of availability, accessibility, quality, economy, ecology, comfort and security. To be viable, an affordable and sustainable housing model must also be socially acceptable to both consumers and surrounding communities [21]. The shortage of affordable housing in Australian cities has emerged as a major concern. Housing has environmental impacts as well as economic implications and social dimensions. Sustainable housing tends to be unaffordable because of the dual costs of making such housing environmentally sound and the high price of inner-city land. Building more storeys on the lot (e.g. 6 storeys instead of 2 storeys) will help reduce land costs per unit.

The most recent National Housing Supply Council annual report reveals that the gap between demand and supply in Australian cities in 2011 increased by over 28,000 units, to almost 200,000 units [22-23]. This report also notes an acute undersupply of inner-city housing within existing urban (brownfield) areas for low-income earners. What is missing is choice of an urban lifestyle where residents can walk to work or restaurants, which systematically restores health through walking or cycling, while reducing carbon emissions and air pollution.

To achieve the required industry and market transformation we need to develop low carbon systems with elements and components for rapid assembly of buildings, while ensuring user acceptance. This is the topic of the ongoing research project introduced in this article. 


\subsection{An Ongoing Research Project that Studies Two Main Issues}

The aim of the ongoing research, stemming from the described practical gap in infill housing, is to study two problems: firstly, to develop better models of urban infill housing. Then to focus on how the use of cross-laminated timber systems could play an important role in achieving a more livable city through facilitating better models of infill. Results will also be obtained from the in-depth analysis of eight built cases that have recently been constructed using CLT systems.

Modular cross-laminated timber (CLT, also called cross-lam) panels form the basis of low-carbon, engineered construction systems using solid wood panels that can be used to build residential infill developments of 10 storeys or higher. These prefabricated engineered solid wood panel construction systems sequester and store $\mathrm{CO}_{2}$ (timber acts as a carbon sink through conversion of $\mathrm{CO}_{2}$ to biomass in the process of bio-sequestration via photosynthesis). A part of the research project will explore the lifestyle changes more and more Australians are choosing: to move from living in the suburbs to the city centre. There is still a knowledge gap about existing cultural barriers and perceptions of infill timber buildings, and a need to better understand the social acceptance of multi-storey solid wood panel construction (such as CLT) for urban infill apartment living. There is a need for greater densification of our cities and CLT provides an opportunity to address the problem: 'brownfield' and 'greyfield' infill as affordable but attractive medium density housing stock, answering the particular problem of housing shortage and a resistance to 'chicken coops' (most apartment buildings in Australian cities are tall, made of concrete and are not based on needs, offering poor value compared to suburban homes).

Timber is the world's oldest construction material, and has unrivalled carbon credentials. Around 1995, the new engineered timber systems emerged in the well-forested sub-Alpine regions of Germany, Austria and Switzerland. Introducing CLT construction systems to Australian cities would mean: rethinking design and construction standards, a renewed focus on modular prefabricated construction systems via digital design tools; but also a focus on material culture and a different understanding of residential development practice in general. The shift to resource-optimized urban infill buildings constructed with engineered timber systems will require behaviour change, to ensure these buildings will be fully acceptable to their occupants.

Why is wood still perceived as a risky option, compared to the usual concrete and steel? Usually fire, insects and acoustics are named as the risks and reason for prejudice. But in order for prefabricated engineered solid wood panel systems to be effective in Australia, consumer acceptance, availability of resource, knowledge transfer for appropriate design, local fabrication and construction capacity must all be aligned. Otherwise, CLT timber systems will not be feasible due to relative high cost of fabrication and lack of acceptance by potential occupants (buyers).

In this paper the author analyses eight case studies of recently constructed residential timber buildings, all between 4 and 10 storeys in height: seven international and one Australian precedent. These precedents are in London, Vienna, Steinhausen, Berlin and Trondheim; while Australia's first timber high-rise has recently been completed in Melbourne (2012). There is a need to clarify why consumers would want to buy apartments in these buildings, based on in-depth post-occupancy evaluations that involve collecting information from owners, residents, neighbours, architects and 
developers to assess residential life in these multi-storey timber buildings. Such first-hand impressions will be invaluable in encouraging social acceptance of similar timber construction in Australia.

\section{Growing Cities and the Argument for Urban Infill}

Cities are the centre of consumption; they require an enormous concentration of energy, construction materials, water, food and land, which nature cannot provide [24-26]. Brown notes that collecting masses of materials and later dispersing them in the form of garbage, sewage and pollutants in air, water and landfill is challenging municipalities worldwide. All this has urban design implications for housing typologies and densification strategies.

Most of Australia's larger cities have recently developed master plans for the next 20 years, to cater for predicted population growth (Australia is currently predicted to grow from 23 million people in 2012 to 36 million by 2045: COAG [27]), and to achieve this growth by increasing the proportion of urban infill from a current rate of around 40 per cent in the cities of Sydney, Melbourne and Adelaide to a nominated target of 60 to 70 per cent. These cities have identified transit-oriented development (TOD) sites and allow for higher density along transit corridors as key strategy: the master plans of all large Australian cities are strikingly similar in their aims and strategies. This renewed planning focus has led to the Australian government - through the Council of Australian Governments (COAG) and the federal government's Major City Unit - taking a much greater interest in the mechanisms whereby affordable and sustainable inner-city housing can be provided. However, the production of conventional apartment buildings using concrete, aluminium and steel are one-way energy-intensive processes that release large amounts of greenhouse gases into the atmosphere. One strategy to achieve more sustainable and affordable housing is to design and manufacture 'green' assemblies for mass customization of buildings using modular prefabricated low-carbon construction systems. The vision of 'making buildings without making waste' could become a reality [27].

Behaviour change has frequently been listed as the number one barrier to reducing consumption towards pro-environmental behaviour and a more energy and material-efficient, low-carbon future [28-30]. The term 'behaviour' can be defined as an active responsiveness to current environmental issues, believed to be pro-environmental by the person performing the response. Tackling the carbon intensity of development and urban sprawl concurrently requires finding lowcarbon alternatives for urban infill development - for instance, living without car parking space on-site but within easy reach of public transport choices - and not compromising mobility and quality of life. Technology is most effective if it is embedded into a societal framework. However, residents' motivation and commitment to aspire to sustainable living are still not well understood, for example how to best overcome barriers to low-carbon living.

\subsection{Buildings Should Be Like Trees and Cities Like Forests}

Besides our historical, poetic and emotional connections to wood, as a construction material it offers several important environmental benefits. It is renewable, it stores carbon that has been sequestered from carbon dioxide in the atmosphere, it can be rapidly regrown, it provides excellent opportunities for re-use and, when harvested from certified sustainable forestry and properly recycled, it can serve as a carbon-neutral source of energy or construction material. 
'Timber' is what we call wood that has been cut for use as building material. We tend to use both, wood and timber, interchangeably. Timber plays an important role in the debate about how our cities should evolve to accommodate what the government hopes will be an increasing population in coming years without irretrievably damaging the environment.

One cubic metre of wood stores around one ton of $\mathrm{CO}_{2}$, making timber a construction material that can impact positively on the environment. Generally, timber buildings require less primary energy consumption ('primary energy' is the energy form that has not been subjected to any transformation process; it is energy contained in raw fuels and other forms of energy received as input to a system; it can be non-renewable or renewable) and have a lower Global Warming Potential (GWP) than concrete or steel buildings (the difference can be 25 per cent or more). Ideally, shouldn't our buildings be like trees and our cities like forests?

Let's build the same building with half the resources! (Hermann Kaufmann) [31].

2.2. Forests, Trees, Wood Products and Carbon Sinks: Grown by the Sun, Timber Is Materialized Solar Energy and an Efficient $\mathrm{CO}_{2}$ Accumulator

Everything begins with the forest that provides the material and is a decisive climate factor if wood is sourced in a sustainable way from well-managed forests. Residential building construction with wood is now changing, focusing on green supply chains and resource-optimized engineered systems. Timber construction is an efficient method of $\mathrm{CO}_{2}$ storage, as long as the material is obtained using responsible methods of forest cultivation (plantations) and from a certified source that is not too far away (to avoid transport-generated greenhouse gases).

A tree produces oxygen, and absorbs over 1.4 metric tonnes of carbon for every ton of timber grown. One cubic metre of timber stores one tone of $\mathrm{CO}_{2}$. No doubt, steel and concrete are great building materials, until you consider their ecological footprint: 5 per cent of all GhG emissions worldwide come from concrete, while each ton of solid wood panels has sequestered around 1.6 tonnes of $\mathrm{CO}_{2}$. New engineered timber outperforms both concrete and steel: During manufacture a ton of steel emits 1.5 tonnes of carbon; and the production of a ton of cement emits over 1.1 tonnes of carbon. Fast growing softwoods will be the future, planted for laminating into large structural panels.

The aim is to evolve systems and designs in timber to tackle the significant negative environmental impact of buildings. Innovative uses of wood technology offer new ways of constructing efficient and affordable structures that demand fewer resources from the environment while maintaining functionality and aesthetic appeal.

Mid-rise urban infill projects-insertions within the existing urban fabric (not high-density and high-rise, but mid-rise, 4 to 10 storeys) — are gaining in popularity. The inner-city residential buildings of tomorrow will focus on construction speed, carbon emissions and weight reduction by using low-carbon lightweight construction systems and cladding; these prefabricated systems will increasingly use high-performance timber panels such as CLT panels, as these can be easily handled on-site. Building more mid-rise infill with timber is highly desirable, as carbon sequestered in trees is thus stored in wooden building components for the duration of the building's life. This will enable us to turn buildings into 'carbon sinks', while avoiding GhG emissions, and increasing resource efficiency and buildings' adaptability. 
Recently conducted research on sustainable forest management, the lifecycle of wood products and the use of timber in infill construction has attracted the construction industry's interest. For example, new findings report that instead of keeping wood growing in forests for hundreds of years, it is beneficial if the wood is regularly harvested and used in construction (to increasingly replace concrete or steel); in this way, carbon dioxide can be removed from the atmosphere [32]. Only a small portion of Australia's forests are 'carbon dense'; most are lower density open forest or woodland. A considerable proportion is regrowth from previous harvesting and over 90 per cent of timber production is concentrated in those areas.

Lippke and his team have identified a number of possibilities for the use of engineered timber panels to replace fossil fuel-utilizing construction systems of reinforced concrete and structural steel. According to their findings, sustainably managed forest plantations in practice offer a two-way flow of carbon dioxide: they absorb carbon dioxide during their growth and when the tree dies and decays, falls back or burns, the carbon returns to the atmosphere; thus the plantation remains carbon neutral [32]. For instance, Lippke's team calculated that the use of engineered wood joists (weighing around one metric ton) in place of steel floor joists reduces $\mathrm{CO}_{2}$ emissions by approximately 10 tonnes. In another example, the use of wood flooring in place of concrete slab flooring reduced the $\mathrm{CO}_{2}$ emission level to 3.5 tonnes for every ton of wood utilized. Therefore, they recommend: plantation of rapid growth tree species, cropping the wood before the trees become less active, utilizing them in place of steel or concrete in construction, or using the wood as biomass to produce energy or bio-fuels to replace fossil fuels. This suggests that a detailed evaluation of each forest will have to be done, as older forests are slower in their absorption of carbon dioxide, but continue to offer numerous other ecological benefits (e.g. high biodiversity). Life cycle analysis will help to compare the different options' carbon footprints.

Timber is one of few materials that have the capacity to store carbon (other materials, such as straw and bamboo can also store carbon), which means that CLT construction systems are an opportunity to turn building structures into 'carbon sinks'. Contemporary technology has changed both the way in which timber buildings are converted and assembled [33], and how these can be protected against fire, insects and decay [34-35]. Wood is one of the oldest construction materials and one of the most utilized worldwide (more than steel and concrete) in construction [36]. Given its carbon sequestration capacity, wood might well be the construction material of the twenty-first century. Engineered timber from managed forestry, from independently certified sources (i.e., PEFC, FSC), are likely to revolutionize the construction industry and become the material that makes sustainable construction in future possible [37-39].

The energy budgets of products and buildings made of wood show that they may use less energy over their total life cycle (manufacture, use, maintenance and disposal) than can be recovered from the waste products of their production and from their recycling potential at the end of their life cycle: they are energy-positive. No other construction material is so comprehensively energy-efficient and therefore climate effective as wood. (Wegener, Pahler and Tratzmiller, p. 4) [40]. 


\section{What Is Solid Wood Panel Construction and What Advantages Does It Bring?}

According to the Timber Development Association of Australia [41], a cross-laminated timber (CLT) construction system is a structural wood panel system fabricated by bonding together large timber boards with structural adhesives, alternating the grain directions of each layer, to produce a solid, load-bearing timber panel with each layer of the panel alternating between longitudinal and transverse lamellae. CLT is not just a 'product', it's a building system. It has now become a recognised construction system increasingly used in Europe as an alternative to steel and concrete.

Large-format solid timber panels are engineered wood products used as massive load-bearing walls and floor slabs. First developed in Switzerland, Germany and Austria, CLT panels are an extension of the technology that began with plywood and may be best described as 'jumbo plywood', where layers of timber, known as lamellas, are glued together with the grain alternating at 90 degree angles for each layer (thus different from LVL or glue-lam). Cross-laminating layers of wood veneer improves the structural properties by distributing the along-the-grain strength of wood in both directions, and this means that solid wood panels can be used to form complete floors, walls and roofs. The advantages this offers are quite exciting-timber panels are much lighter than concrete, more easily worked and easier and safer to erect [42-44]. In addition, it is well-known that a timber-based construction can withstand fire far longer than a steel building, which when softened by heat might suddenly collapse, whereas a burning wooden beam can more often still support a cross-section of sufficient load-bearing capacity for long enough to evacuate a building.

CLT construction technology for multi-storey residential buildings was further developed in Europe in the 1990s and has been widely used in European countries (e.g., produced under the names Brettsperrholz or Massivholz, by highly qualified medium-sized manufacturers and imported to other countries, such as the United Kingdom) as a modern construction method. More recently this construction system has been adopted by Canada and New Zealand, utilising opportunities for industrialised offsite construction methods.

A recent scoping study identified the research needed and existing capacity to deliver solid wood panel buildings for infill development in Australia using CLT construction systems [45]. Key stakeholders were interviewed for their perspectives about CLT including the perceived barriers to and/or opportunities for using CLT buildings and establishing CLT construction systems in Australia. There is still some confusion between acceptance and skepticism (consumer resistance) about the introduction of CLT apartment buildings in Australia.

While the scoping study reveals a keen interest in and willingness to adopt CLT systems for multi-residential development between architects, the main barriers are: a lack of local manufactured product with which to enhance familiarity; uncertainty about gaining building approvals for fire performance (including prevention of fires during construction); and the social acceptance or liveability of timber buildings for infill development by potential occupants [45]. Other barriers to CLT constructions are perceived disadvantages of wood as a building material because people are afraid that it might lead to higher maintenance and could lack durability (usual concerns include fire, acoustics, moisture and vermin protection): it requires protection from insects, such as termites, or fungi, and it could be exposed to decay or rot. However, the technical challenges are widely resolved. 
Provided there is a rain screen facade protecting the timber panels, condensed water will dry out. Overall, timber is a highly resilient and flexible, natural re-growing building material.

There are a number of clear benefits of solid wood panel buildings, such as the ones built with CLT. The following list is drawn from our own review of such buildings, a review of research papers, of wood product industry strategies and from discussions with industry stakeholders in the supply chain:

- the speed with which the structure of CLT constructed buildings can be assembled on-site (built at least 30 per cent faster, because much of it is prefabricated and lighter);

- the acoustic and thermal performance of massive CLT panels, which potentially reduce the level of additional insulation needed for energy efficiency and sound deadening;

- the expected higher fire performance of CLT compared to timber-framed buildings (high-density massive wood panels char rather than ignite, and the charring creates a fire barrier, as the charred layers protect the panels' load-bearing capacity);

- storage of carbon in the timber of each CLT building $\left(\mathrm{CO}_{2}\right.$ sequestration);

- a reduced carbon footprint for timber buildings from responsibly sourced wood compared to steel, concrete and aluminium counterparts (the low energy used to make the building materials means reduced embodied energy);

- lighter: resource-reduced construction with only a quarter of the weight compared with a concrete building, and significantly reduced waste;

- the ease and affordability of heating and cooling a CLT dwelling, providing a healthy indoor climate (resulting in reduced operational energy and smaller energy bills for residents).

In the 1970s, off-site manufacture of building components led to industrialized uniformity and monotonous architecture. But Building Information Modelling (BIM), using computer-aided calculation and production methods, allows for a diversity of individual solutions (mass-customization). Accurate off-site prefabrication of CLT panels enables modular construction and enhances the use of efficient, digital design techniques. CLT wall panels can be precision cut off-site to create window and door openings and in some cases are already fitted with insulation, external cladding and windows. Prefabricated panels are also used for floors, roofs, ceilings, lift shafts and stairwells in some multi-storey buildings [46-48]. The review of cases in the scoping study highlighted the rapid on-site construction that may be as short as three to four months for buildings of up to nine storeys [45]. Such short construction times, compared to traditional multi-storey construction methods, reduce noise impact, the risk of accidents on-site and the need for traditional construction equipment such as fixed cranes. CLT systems provide a precise construction process that allows faster completion, increased safety on site, less disruption to the neighbourhood and less waste. Traditionally around 40 per cent of all solid waste comes from construction and demolition. These benefits are not, of course, limited to CLT buildings but will be part of all modern methods of construction that utilize prefabricated wall, floor and roof construction elements.

While there is currently no Australian manufacturing facility, mechanisms are in place whereby CLT panels can be supplied from Europe (at the time of writing companies in New Zealand and Canada have recently started to produce CLT panels; and Australian developer Lend Lease is considering establishing a domestic supply chain, based on radiata pine, with the aim to end the reliance on overseas products; personal communication with Lend Lease, 2012). Recent material 
testing has shown that the quality of pine in Australia can be considered equal to European spruce and $\mathrm{NZ}$ radiata.

The first CLT multistorey residential building in Australia is the residential tower at 807 Bourke Street in Victoria Harbour (Docklands) in Melbourne, built in 2012: a 10-storey apartment building constructed entirely in CLT panels by Lend Lease in collaboration with KLH (Austrian panel manufacturer). The construction period was short, from May to October 2012.

Having recognized the unsustainable nature of many current practices - such as using carbon-intensive materials such as reinforced concrete-we now have the opportunity through massive wood construction to develop more inherently sustainable approaches.

\section{Examples of CLT-Constructed Buildings in an Urban Context: European Case Studies and a First Application in Australia}

How can consumers be influenced to accept apartments constructed entirely of timber? The use of post-occupancy evaluation (POE) of new, affordable and sustainable housing projects is a promising approach for analysing occupant comfort, user behaviour and energy consumption. It will enable researchers to develop and validate an 'ideal' model for infill housing using CLT for Australian cities. Surprisingly, there have been few studies of housing using POE or studies that specifically assess whether the social aims of such developments are being achieved [49,50].

In Europe, construction of solid wood panel multi-storey apartment buildings has increased recently. Projects in European cities that have been built or are under way include:

- In Austria: Ölzbündt; the LifeCycle Tower (2012), Dornbirn; Schützenstrasse, Innsbruck; Am Muehlweg (2004), Spöttlgasse (2005), Wagramer Strasse (2012) in Wien; Samermösl, Salzburg; Impulse Centre, Graz; Ammerwald Alpine Hotel, Tyrol.

- In Switzerland: Wyler Park, Berne; currently over 1000 apartments in Zurich are under construction.

- In Germany: projects in Aichach, Hamburg and in Berlin; for instance, the 5-storey apartment building in Goerschstrasse in Berlin-Pankow.

- In Italy: a 9-storey apartment building with 130 units is under construction in Milan.

- In the UK: various projects have been completed or are in the pipeline, for instance in Hackney, London (Stadthaus, Bridport). One of the earliest projects was the 5-storey office and residential building in Waterson Street, London, by Quay2c Architects (2004).

- In Norway: projects in Trondheim and Stavanger have been completed.

- In Finland: a large complex in Helsinki, the 'Low2No' project, is under construction.

- In Canada: the Earth Sciences Building for UBC in Vancouver has been completed (a hybrid structure); a 20-storey wood tower for Vancouver is in planning.

- In New Zealand: the 5-storey timber building for Massey University in Wellington has been completed.

In Australia, only a few CLT buildings have been designed and submitted for development approval so far (e.g. the 10-storey Bourke St 'Forté' building at Victoria Harbour, which has been completed in 2012, is the first CLT building). Construction costs for apartment buildings are still significantly 
higher than costs for houses; however, CLT construction has the capacity to change this situation in the coming years. A development in the Sydney area (MacArthur Gardens in Western Sydney), and three in Adelaide (the 4-storey Sturt Street housing project in the city centre; an 8-storey student housing project on top of the existing Topham Mall car park in Currie Street; and an 8-storey apartment building at Bowden Urban Village) propose CLT buildings, although the designs are still only in concept form at the time of writing. Figures 2 to 11 illustrate some of the recently built residential building cases constructed with CLT systems.

Figure 2. (a) and (b). The 10-storey 'Forte'' timber apartment building in Bourke Street, Victoria Harbour, in Melbourne Docklands, 2012.

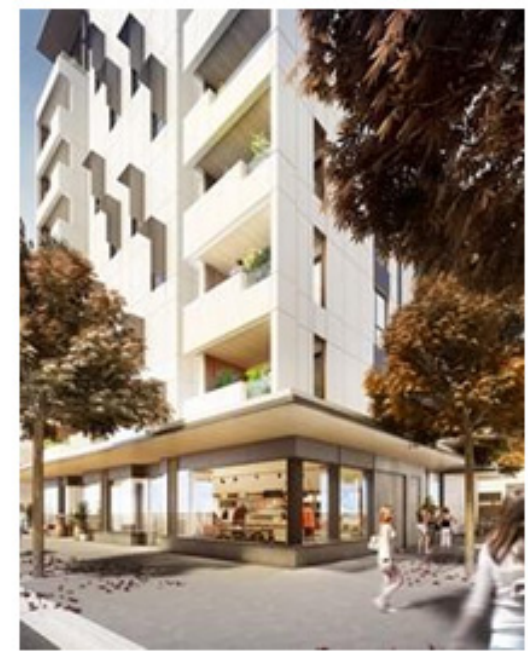

(a)

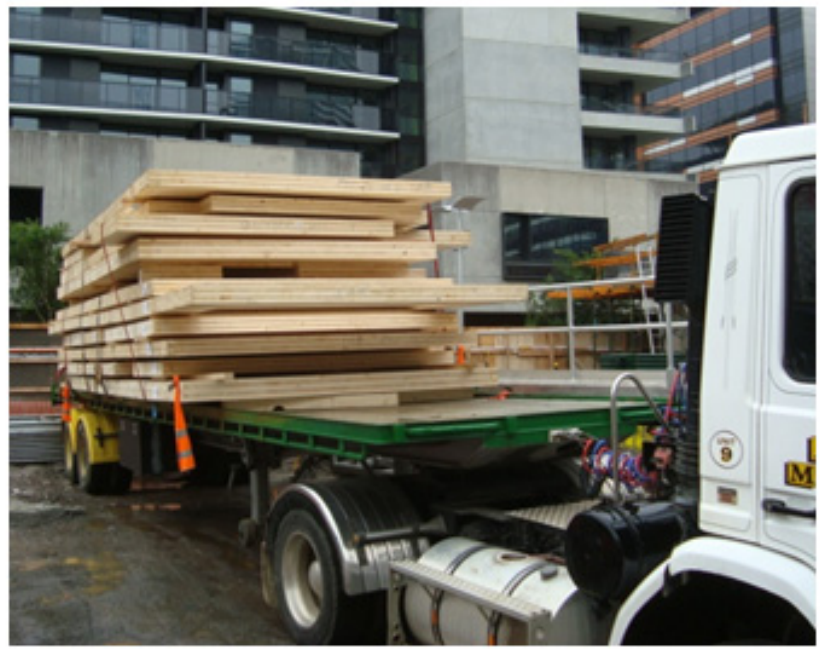

(b)

According to Lattke and Lehmann [51], construction with CLT panels in Europe since the late 1990s has resulted in some ground-breaking demonstration projects, a number of which they have analysed in detail. At the moment, almost every larger timber building is a prototype. Kaufmann argues: 'To achieve greater certainty in terms of planning and the granting of building permits, standardisations are necessary' (Kaufmann, p. 42) [52]. The interest in an uptake of CLT construction is immense: CLT systems were first used in the UK's construction industry only ten years ago, but it has quickly grown, with now (2012) around one hundred CLT projects proposed in the UK-especially in the mid-rise residential and school building sectors.

Table 1 lists the eight selected built cases and summarizes some aspects of these multi-storey apartment buildings using massive wood panel construction: these relatively complex residential projects in Europe provide an insight into the diversity of design possibilities using the panel system. An overview of the growing market for CLT construction from this research will be of interest to players in all phases of the construction industry. 
Table 1 (a). Cross-laminated timber (CLT) buildings: seven international case studies of residential buildings above three storeys.

\begin{tabular}{|c|c|c|c|c|c|}
\hline Case & Height & Dwellings & $\begin{array}{l}\text { Cost in } \\
\text { millions }\end{array}$ & Architects & Comments \\
\hline $\begin{array}{l}\text { 1. Bridport } \\
\text { House, } \\
\text { Hackney, } \\
\text { London, UK } \\
\text { (completed Oct. } \\
2011 \text { ) }\end{array}$ & 8 storeys & $\begin{array}{l}41 \text { units } \\
(1-4 \\
\text { bedroom } \\
\text { apart- } \\
\text { ments) }\end{array}$ & $£ 5.9$ & $\begin{array}{l}\text { Karakusevic } \\
\text { \& Carson, } \\
\text { London with } \\
\text { Eurban; } \\
\text { Stora Enso }\end{array}$ & $\begin{array}{l}\text { Code Level } 4 \text { and Lifetime Homes } \\
\text { construction time: } 12 \text { weeks, Oct-Nov } 2010 \\
\text { CLT delivered by Stora Enso ( } 30 \text { deliveries } \\
\text { to site). }\end{array}$ \\
\hline $\begin{array}{l}\text { 2. Stadthaus, } \\
\text { apartment } \\
\text { building, } 24 \\
\text { Murray Grove, } \\
\text { Hackney, } \\
\text { London } \\
\text { (completed Jan. } \\
\text { 2009) }\end{array}$ & $\begin{array}{l}9 \text { storeys, } \\
\text { of which } 8 \\
\text { storeys are } \\
\text { in CLT }\end{array}$ & $\begin{array}{l}29 \text { apart- } \\
\text { ments, } \\
\text { partially } \\
\text { social } \\
\text { housing. }\end{array}$ & $£ 3.5$ & $\begin{array}{l}\text { Waugh \& } \\
\text { Thistleton } \\
\text { Architects } \\
\text { with } \\
\text { Techniker } \\
\text { Limited } \\
\text { Engineers }\end{array}$ & $\begin{array}{l}\text { Used KLH CLT: } 926 \text { cubic metres } \\
\text { CLT walls, floor slabs; timber stair and lift } \\
\text { cores. Each apartment has its own } \\
\text { internal balcony. } \\
\text { Timber assembled using four carpenters in } \\
12 \text { weeksone floor each } 3 \text { days, total build } \\
\text { took only } 49 \text { weeks. } \\
\text { The potential for creep shortening due to } \\
\text { compression under load is negligible for the } \\
\text { walls and } 0.6 \text { millimetres ( } 0.02 \text { inches) for } \\
\text { the floors. }\end{array}$ \\
\hline $\begin{array}{l}\text { 3. Svartlamoen } \\
\text { apartment } \\
\text { building, } \\
\text { Trondheim, } \\
\text { Norway, } \\
2004-05\end{array}$ & $\begin{array}{l}5 \text { storeys } \\
\text { in CLT, } \\
\text { measures } \\
6 \times 22 \mathrm{~m} \\
\text { in plan }\end{array}$ & $\begin{array}{l}2 \text { buildings } \\
\text { with an } \\
\text { area of } \\
1080 \text { sqm. } \\
\text { Four floors } \\
\text { contain } \\
\text { units of } \\
120 \text { sqm }\end{array}$ & $€ 2.16$ & $\begin{array}{l}\text { Brendeland } \\
\& \\
\text { Kristoffersen } \\
\text { Architects, } \\
\text { Trondheim }\end{array}$ & $\begin{array}{l}\text { Also contains commercial rooms in } \\
\text { ground floor. } \\
\text { Clad with Norwegian larch. Untreated } \\
\text { timber surfaces of the load-bearing elements } \\
\text { are exposed on the inside. } \\
\text { Four workers managed to erect the main } \\
\text { structure in just ten working days. Public } \\
\text { housing, apartments mainly occupied } \\
\text { by students. }\end{array}$ \\
\hline $\begin{array}{l}\text { 4. Am } \\
\text { Muehlweg } \\
\text { housing project, } \\
1210 \text { Vienna- } \\
\text { Floridsdorf, } \\
\text { Austria (new } \\
\text { district built in } \\
\text { CLT, various } \\
\text { architects), } \\
\text { 2005-06 }\end{array}$ & $\begin{array}{l}3 \text { and } 4 \\
\text { storeys in } \\
\text { CLT on a } \\
\text { concrete } \\
\text { basement }\end{array}$ & $\begin{array}{l}70 \\
\text { apartments } \\
\text { in several } \\
\text { CLT } \\
\text { buildings, } \\
200 \\
\text { residents, } \\
\text { total } \\
\text { approx. } \\
7000 \mathrm{sqm}\end{array}$ & $€ 11$ & $\begin{array}{l}\text { Hubert } \\
\text { Riess, } \\
\text { Dietrich } \\
\text { Untertrifalle, } \\
\text { and } \\
\text { Hermann \& } \\
\text { Johannes } \\
\text { Kaufmann, } \\
\text { Schwarzach, } \\
\text { Vorarlberg, } \\
\text { Austria }\end{array}$ & $\begin{array}{l}\text { Three interconnecting sites } \\
\text { optimum exploitation of ecological and } \\
\text { economic benefits of timber and } \\
\text { mixed constructions } \\
\text { terraced houses and an L-shaped building } \\
\text { surround an internal courtyard, offering a } \\
\text { free area for communal use } \\
\text { low energy standard according to } \\
\text { BBS-performs at } 30 \mathrm{~kW} / \mathrm{sqm} / \mathrm{pa} \text { (Passiv } \\
\text { Haus Standard), 'Timber Passive Houses'. }\end{array}$ \\
\hline
\end{tabular}


Table 1 (a). Cont.

\begin{tabular}{|c|c|c|c|c|c|}
\hline Case & Height & Dwellings & $\begin{array}{l}\text { Cost in } \\
\text { millions }\end{array}$ & Architects & Comments \\
\hline $\begin{array}{l}\text { 5.Wagramer- } \\
\text { strasse, corner } \\
\text { Eipeldauer } \\
\text { Strasse, Vienna, } \\
\text { Austria, 2012- } \\
\text { 5.Wagramer- } \\
\text { strasse, corner } \\
\text { Eipeldauer } \\
\text { Strasse, Vienna, } \\
\text { Austria, } \\
\text { 2012-13 }\end{array}$ & $\begin{array}{l}\text { 6-storey } \\
\text { main } \\
\text { building } \\
\text { and three } \\
\text { 3-storey } \\
\text { fingers, in } \\
\text { CLT } \\
\text { panels, on } \\
\text { top of 1 } \\
\text { storey } \\
\text { concrete } \\
\text { base }\end{array}$ & $\begin{array}{l}101 \text { units } \\
\text { (public } \\
\text { housing), } \\
\text { constructed } \\
\text { in only } \\
10 \text { weeks }\end{array}$ & 4 & $\begin{array}{l}\text { Michael } \\
\text { Schluder } \\
\text { with } \\
\text { Hagmueller } \\
\text { Architekten, } \\
\text { Vienna }\end{array}$ & $\begin{array}{l}\text { The result of a design competition, the City } \\
\text { of Vienna is driving its 'Wood in the City' } \\
\text { program ahead with high quality public } \\
\text { housing. This initiative has a focus on } 3 \text { to } 8 \\
\text { storey timber construction for } \\
\text { inner-city locations. } \\
\text { Austria's highest timber apartment building, } \\
\text { with } 7 \text { storeys ( } 6 \text { in CLT, on top of a } \\
\text { concrete storey); a hybrid construction with } \\
\text { staircases in concrete. In total } 2400 \mathrm{~m}^{3} \\
\text { ( } 19,500 \text { sqm) of CLT panels, manufactured } \\
\text { by Binderholz, were used; these panels have } \\
\text { stored approx. } 2400 \text { tons of } \mathrm{CO}_{2} \text {. }\end{array}$ \\
\hline $\begin{array}{l}\text { 6. 'e3' } \\
\text { apartment } \\
\text { building, } 3 \\
\text { Esmarchstrasse, } \\
\text { Berlin } \\
\text { Prenzlauer } \\
\text { Berg, Germany, } \\
2008 \\
\text { (completed } \\
\text { April 2008) }\end{array}$ & $\begin{array}{l}\text { 7-storey } \\
\text { urban infill } \\
\text { (height } \\
23 \mathrm{~m} \text { ) }\end{array}$ & $\begin{array}{l}7 \\
\text { apartments } \\
\text { (one large } \\
\text { apartment } \\
\text { per floor) }\end{array}$ & $\begin{array}{c}€ 2.5 \\
\text { (around } \\
€ 2,100 / \mathrm{s} \\
\mathrm{qm} \text { ) }\end{array}$ & $\begin{array}{l}\text { Kaden \& } \\
\text { Klingbeil } \\
\text { Architekten, } \\
\text { Berlin }\end{array}$ & $\begin{array}{l}\text { German building regulations changed in } \\
\text { 2002, allowing timber construction (a } \\
\text { hybrid structure, using CLT and glue-lam) } \\
\text { up to } 5 \text { storeys. } \\
\text { This } 7 \text {-storey, apartment infill building has } \\
\text { been developed in collaboration with the } \\
\text { Berlin Fire Department; the concrete escape } \\
\text { staircase is separated from the main } \\
\text { building. } 40 \% \text { less weight compared to } \\
\text { concrete; performs at } 27 \mathrm{kWh} / \mathrm{sqm} / \mathrm{a} \text {. } \mathrm{CO}_{2} \\
\text { neutral building. }\end{array}$ \\
\hline $\begin{array}{l}\text { 7. Holzhausen } \\
\text { apartment } \\
\text { building, } \\
\text { Steinhausen, } \\
\text { CH, } 2006\end{array}$ & $\begin{array}{l}6 \text { storeys- } \\
4 \text { storeys } \\
\text { in CLT } \\
\text { panel, on } \\
\text { concrete } \\
\text { base }\end{array}$ & $\begin{array}{l}12 \text { units (2 } \\
\text { apartments } \\
\text { per floor) } \\
150 \text { and } \\
166 \text { sqm in } \\
\text { size. }\end{array}$ & $€ 4$ & $\begin{array}{l}\text { Scheitlin, } \\
\text { Syfrig \& } \\
\text { Partner } \\
\text { Architekten, } \\
\text { Luzern }\end{array}$ & $\begin{array}{l}\text { Switzerland's first six-storey } \\
\text { timber building; } \\
\text { fire protection standard in Switzerland, } \\
\text { introduced in January 2005, 60-minute fire- } \\
\text { resistance capability. }\end{array}$ \\
\hline
\end{tabular}


Table 1 (b). Australia's first multi-storey CLT apartment building.

\begin{tabular}{|c|c|c|c|c|c|}
\hline Case & Height & Dwellings & $\begin{array}{l}\text { Cost in } \\
\text { millions }\end{array}$ & Architects & Comments \\
\hline $\begin{array}{l}\text { 8. 'Forté', } 807 \\
\text { Bourke Street, } \\
\text { Victoria Harbour, } \\
\text { Melbourne, } \\
\text { Victoria, } \\
\text { Australia, } 2012\end{array}$ & $\begin{array}{l}\text { 10-storey } \\
\text { residential } \\
\text { tower } \\
(32.17 \mathrm{~m} \\
\text { high }), 9 \\
\text { storeys of } \\
\text { CLT on a } \\
\text { concrete } \\
\text { podium }\end{array}$ & $\begin{array}{l}23 \\
\text { apartments } \\
\text { and retail in } \\
\text { ground floor, } \\
\text { fully } \\
\text { sprinklere; } \\
\text { no car } \\
\text { parking } \\
\text { space. }\end{array}$ & AUS $\$ 11$ & $\begin{array}{l}\text { Lend Lease } \\
\text { (Australia), } \\
\text { in-house } \\
\text { design }\end{array}$ & $\begin{array}{l}\text { Australia's first CLT timber high-rise } \\
\text { building. CLT panels manufactured and } \\
\text { imported to Melbourne from KLH, } \\
\text { Austria. Site work commenced in } \\
\text { February and completed in October } \\
\text { 2012. Forté includes } 7 \text { one-bedroom } \\
\text { apartments ( } 59 \text { square metres), } 14 \text { two- } \\
\text { bedroom apartments ( } 80 \text { square metres) } \\
\text { and two penthouse apartments with two } \\
\text { bedrooms (102 square metres). }\end{array}$ \\
\hline
\end{tabular}

\subsection{CLT Building 1: 'Stadthaus' Multi-Apartment Building in Murray Grove, Hackney, London}

The 'Stadthaus' was designed by Waugh and Thistleton Architects, and built in 2008. The 9-storey building is a project of local developer Telford Homes and the Metropolitan Housing Association. There are 19 private apartments, 10 social housing units and a residential housing office located in the building. The apartments are a mix of one, two and three bedroom accommodation [53]. The brief of the client was that it needed to look and feel the same as if built in concrete, to avoid issues of acceptance. After the ground floor was constructed the remaining construction was undertaken without a fixed crane in place, and each storey was assembled in three days using four carpenters. The entire building process took 49 weeks with the construction of the 8 CLT storeys taking only 12 weeks. The CLT for walls and floors was sourced from Austria and constructed using the system of KLH in Austria: like a kit of parts, the CLT panels are up to 12 metres long (limited by size for transport; 12 metres is the largest size that could be transported through the channel tunnel to the UK) and weighed a maximum of 15 tonnes. The weight limit allowed use of a mobile crane. The foundations are cast in situ concrete piles designed to accept the weight of a concrete framed building of similar size - a decision to ensure procurement alternatives [53]. Wells notes that the lift core and stairwells are all made in timber. The architect stated that meeting building code requirements for fire was relatively straightforward, relying on the self-protecting properties of timber which can retain its strength during fire for longer periods than steel [54-55]. At the beginning, the unusual construction system was kept secret from the apartment buyers by the developer and all internal wall surfaces were covered with gypsum panels, to avoid confusing potential buyers. However, the innovative timber structure was leaked to the press and stories were published in the newspaper. Apparently, all 29 apartments were sold within two hours to buyers, many enthusiastic about the more environmentally friendly construction method. 
Figure 3. (a) 'Stadthaus' and (b) Whitmore Road, both in London Hackney, during construction. Stadthaus has achieved global recognition as the world's tallest wooden residential structure.

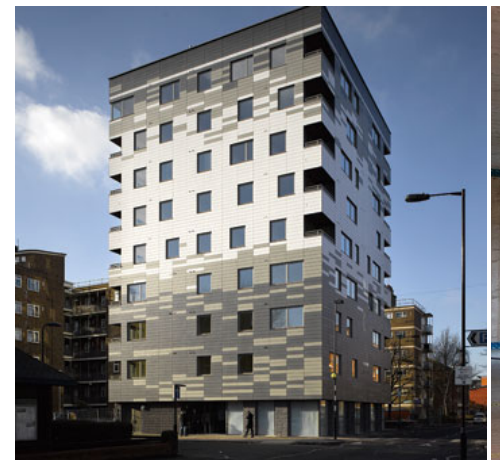

(a)

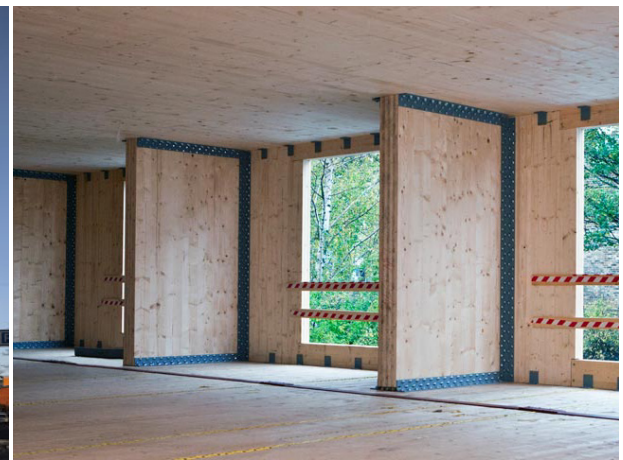

(b)

\subsection{CLT Building 2: Bridport House, Hackney, London}

The eight-storey Bridport House is (at the time of writing), with Stadthaus, the tallest all cross-laminated timber (CLT) building in the UK (both were constructed for the same developer client and the London Borough of Hackney). Both have pushed the boundaries of CLT construction up to eight storeys, although Stadthaus is marginally taller at nine storeys, featuring a concrete ground floor, whereas Bridport House is CLT from the ground up. Bridport House replaces an original 1950s block with 41 new homes in two joined blocks, one eight storeys and the other five storeys high. All elements from the ground floor upwards are of cross-laminated timber, manufactured and supplied from Austria by Stora Enso Wood Products-including the lift shaft. Below ground level the raft, foundations and lift pit are of reinforced concrete. Often in such projects the ground floor will be concrete because it is used for retail and needs larger facade openings. At Bridport House, however, the lowest two floors are occupied by residential maisonettes that have been oriented in a different direction from the apartments above. In the design phase, reinforced concrete and structural steel was compared in detail with the use of a CLT system (Eurban ran a detailed comparative analysis). There are several reasons why CLT was selected: one was weight. CLT is considerably lighter than the alternative structural materials, as a large Victorian sewer runs beneath the site and point loads needed to be avoided. Speed of construction was another benefit of CLT which can take as little as half the time to construct as a conventional reinforced concrete frame. In addition, the construction process is far less likely to be interrupted in bad weather conditions. Stephen Powney notes in Timber and Sustainable Building Magazine that, despite the transport, carbon saving over steel and concrete was 2113 tonnes; the amount of sequestered carbon is the equivalent saving to providing 20 per cent of the building's energy requirement in use for 139 years [56]. The building was completed in October 2011. Probert noted that CLT was becoming very competitive with UK construction companies, partly due to the carbon sequestration in the structures. 
Figure 4. (a) and (b) Bridport House, Hackney, London, was completed in August 2012.

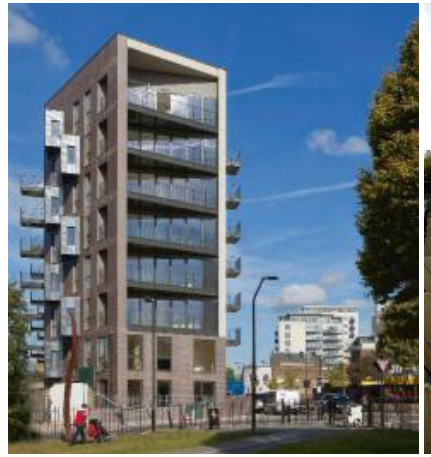

(a)

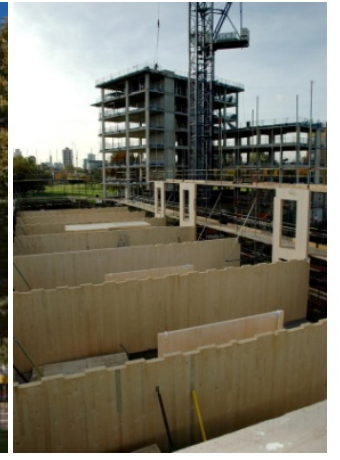

(b)

\subsection{CLT Building 3: Svartlamoen Multi-Apartment Building in Trondheim, Norway}

This development (architects: Brendeland and Kristoffersen, Trondheim, 2005) consists of two buildings with an overall area of around $1000 \mathrm{sqm}$ [51]. The main five-storey building, which measures $6 \mathrm{~m} \times 22 \mathrm{~m}$, also contains rooms that can be used commercially, and the four upper floors contain units of $120 \mathrm{sqm}$ designed to accommodate 5 persons each. The entire construction was made out of solid CLT boards and clad with Norwegian larch. The untreated timber surfaces of the load-bearing elements are exposed on the inside (see Figure 5). The use of prefabricated elements reduced total construction time significantly ( 9 months, about half the usual time). The efficient assembly of the timber elements allowed four workers to erect the main structure in just 10 working days. This project has provided student housing and was selected through a design competition set up by the city municipality, drawing on grants from the central government for sustainable and innovative buildings. The building was controversial and one of the architects (Brendeland) commented that 'the day the Svartlamoen housing block was opened, concrete companies took out a full-page advert in the city newspaper showing a blazing timber building, a scare tactic focusing in on timber's fire risks' [57]. The following Figures 5 and 6 introduce some of the occupants of the selected cases. A post-occupancy evaluation for the building in Trondheim is currently underway. In April 2012, the author met with residents Mats and Hella to discuss their lifestyle choices. He learnt that there is now a long waiting list of students to move into this building; it has become very popular to be associated with this green building. The occupants mentioned that they like the idea that the building materials are recyclable and all tenants are conscious of the sustainability of the building, appreciating its particular 'timber qualities', for example the healthy indoor climate. 
Figure 5. Svartlamoen project, Trondheim, Norway-Exterior view with residents Mats (a) and Hella (b).

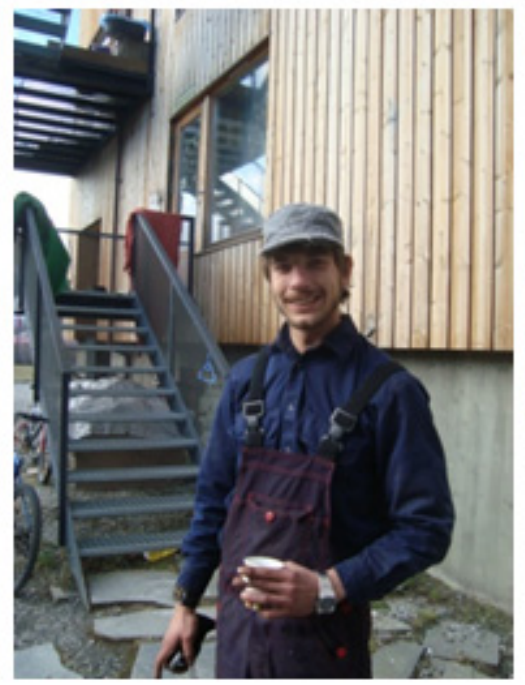

(a)

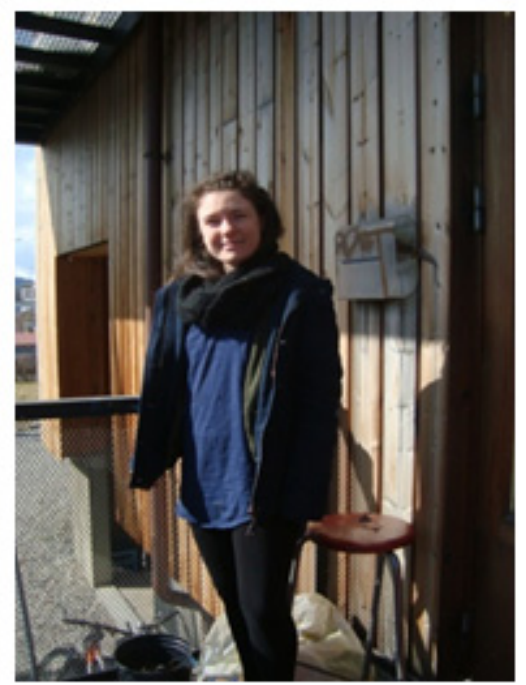

(b)

\subsection{CLT Building 4: Am Muehlweg Complex, Vienna-Floridsdorf}

The Am Muehlweg project was designed by Hubert Riess, Dietrich and Untertrifaller, and the construction cooperative Hermann and Johannes Kaufmann architects. One hundred public-sector apartments were built on each of three interconnecting plots, with the emphasis on the optimum exploitation of the ecological and economic benefits of timber and mixed constructions. Terraced houses and an L-shaped building surround an internal courtyard, creating a communal area. In total, the project provides $6750 \mathrm{sqm}$ in 70 dwellings in 13 buildings (a detailed description of the project is in Kaufmann and Nerdinger [58]). The three-storey structures made from prefabricated CLT panels built on top of a concrete base were constructed in 15 months. The four-storey buildings offer two different solutions. The north-south-oriented terraced concept, with its maisonettes, has a twostorey timber construction on the second floor erected on top of a ceiling of reinforced concrete. The three-storey structures made from CLT elements are built on top of the concrete base of the east-west-oriented units (see Figures 6 and 7 for images of the project). The entire four storeys of the building are clad in larch. An obligatory fire protection belt was included in the development's design. Lattke and Lehmann [51] note that a major success of the project was the cooperative working relationships between planners and representatives of the public authorities, who discussed and developed alternatives and shared specific knowledge on timber construction. In April 2012, the author met with residents to discuss their lifestyle choices and reasons to decide for living in the building. The findings are similar to the Norwegian case: the occupants are very much aware of the 'green' construction method; they like the idea that the building materials are natural, and are conscious of the sustainability aspects of the buildings. 
Figure 6. (a) and (b) Resident Barbara of the Am Muehlweg project in Vienna, Austria.

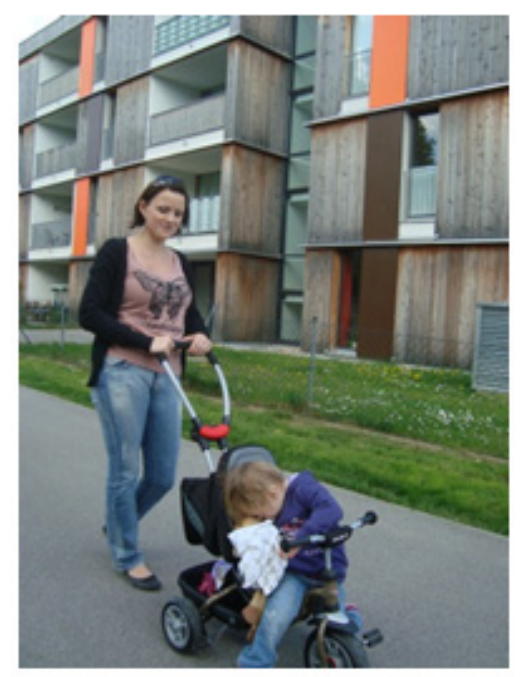

(a)

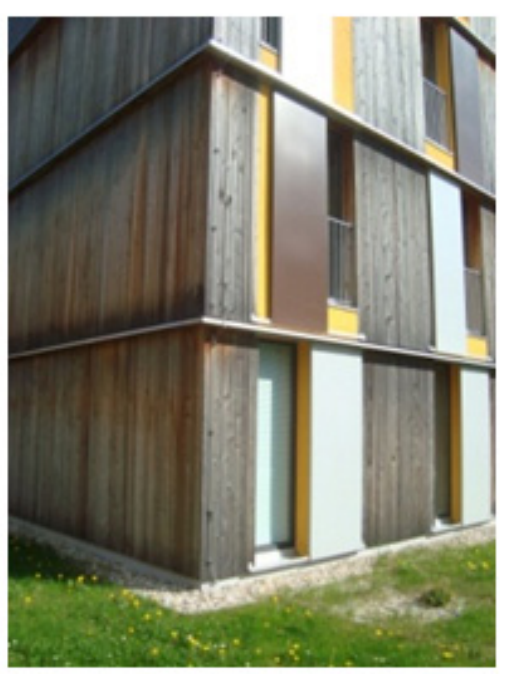

(b)

Figure 7. Aerial photo of Vienna, Am Muehlweg, 4-storey CLT residential buildings, designed by various architects, 2005-2006.

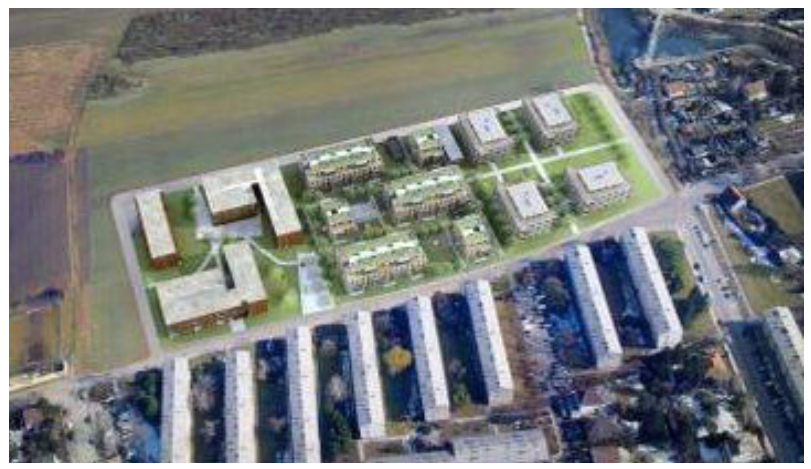

\subsection{CLT Building 5: Wagramerstrasse Public Housing, Vienna}

This is Austria's highest residential building constructed with CLT systems: 101 apartments in a 7-storey slab along Wagramerstrasse and three 3-storey fingers forming courtyards. Six storeys of CLT sit on top of a concrete podium [59]. The solution is the outcome of a 2009 design competition organized by the City of Vienna. The build is a composite structure of concrete cores with the CLT system; engineer Wolfgang Winter predicts that 'most large-scale multistorey timber buildings in future will be hybrid structures, where sound insulation is typically added via the use of concrete or screed' [60]. The $2400 \mathrm{~m}^{3}$ timber structure stores around 2400 tonnes of $\mathrm{CO}_{2}$, which equals the annual emissions of 1630 cars. The panels were manufactured by Binderholz Bausysteme and the project is completed in February 2013. The apartments are 2, 3 and 4 bedroom units of 60 to 105 sqm in size; some are maisonettes. 
Figure 8. (a) and (b) Wagramerstrasse apartment complex, Vienna, which is part of the city's 'Holz in der Stadt' initiative, which allows now timber buildings up to 32 metres in height; under construction. Cores and ground floor podium are in concrete.

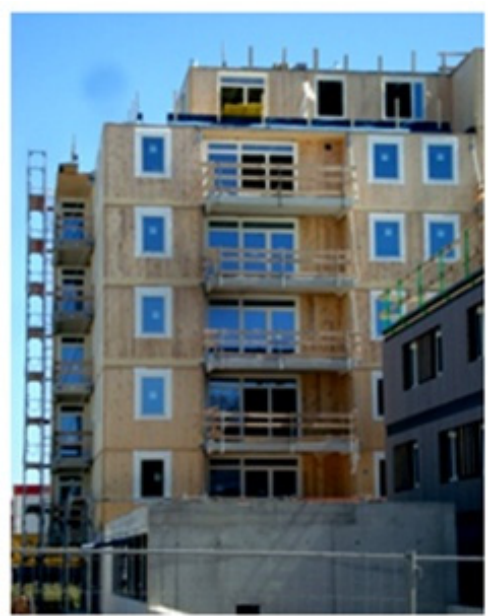

(a)

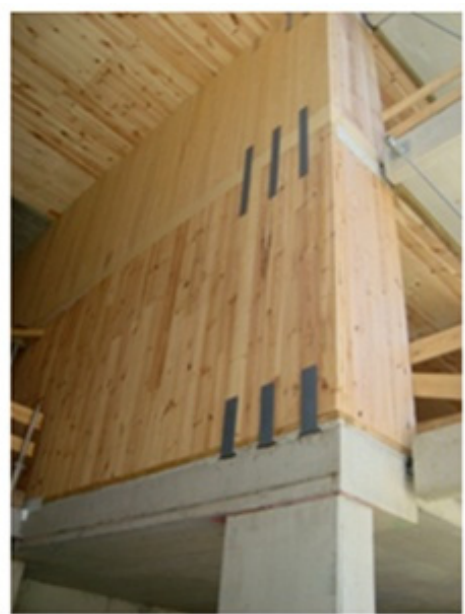

(b)

\subsection{CLT Building 6: The 'e3' Multi-Apartment Building at 3 Esmarchstrasse, in Berlin Prenzlauer Berg}

The e3 apartment building, designed by architects Kaden and Klingbeil was only possible as a special exception to Berlin's stringent building code. It is a seven-storey timber frame building, something still uncommon in 'stone-built Berlin'; a hybrid construction using CLT panels for walls and glue-lam elements (the primary structural floor panels are in 'Brettstapel' method). Today, the majority of large multistorey timber structures are composites of different engineered timber systems [61]. The wooden floor slabs are packaged in fire-retardant gypsum fibreboard, as are the solid wooden walls. The wood-concrete composite ceilings feature, on their underside, timber planks covered with a fire prevention glaze. Tenants have laid flooring of their choice on the concrete upper side. Apart from two concrete cores, which run the entire length of the building for stability and installation, the apartment layouts are flexible and can be subdivided and arranged as desired. The results are loft-like spaces and small ateliers, built in an extremely short construction phase. The gross square metre prices of 1900 to 2400 Euros, which vary from floor to floor within the building, are comparable to conventional developer projects in concrete frame. Close cooperation with the fire brigade was necessary to obtain permission; the building's design and fire safety measures (such as short escape routes) proved sufficient to satisfy the fire brigade: a free-standing external staircase made of concrete, positioned along the fire wall of the adjacent building - as it can neither catch fire nor fill with smoke. The external façade is plastered and the white rendering makes it look like conventional urban infill, not recognisable as a wooden building. The building has high-quality insulation and maximum annual energy consumption is only $40 \mathrm{kWh}$ per square metre. In Germany, the trend towards timber-framed and CLT buildings, advanced years ago by the Bavarian State Building Authority's research, pilot projects and amended building regulations, has now arrived in densely populated inner cities (such as Berlin) in the form of infill prototypes. Whether or not this sustainable style of building will become more widespread will also depend on the wider acceptance and the willingness of relevant authorities to be flexible in approving the new construction methods. 
Figure 9. The 'e3' infill building, Esmarchstrasse, Berlin, a 7-storey residential urban infill building with a concrete staircase tower; unfortunately, the building does not expose any timber.

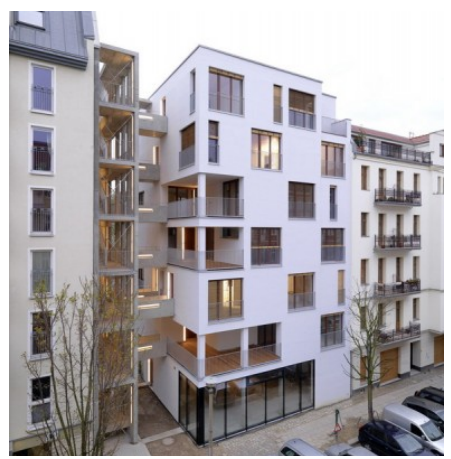

Figure 10. Holzhausen apartment building in Steinhausen, Switzerland.

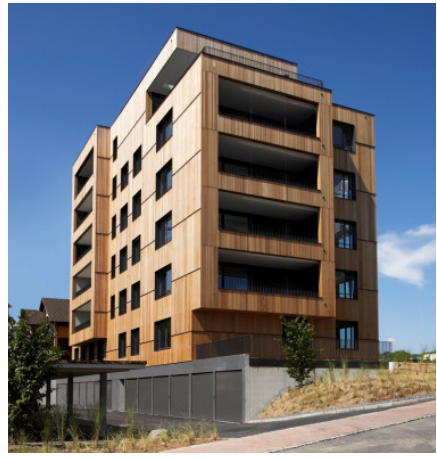

\subsection{CLT Building 7: The Holzhausen Apartment Building in Steinhausen, Switzerland}

This apartment building designed by architects Scheitlin, Syfrig and Partner (in collaboration with manufacturer Holzbau Renggli AG), is Switzerland's first six-storey timber building, with a four-storey timber-framed construction on top of a concrete base. The project replaced an existing building and makes more intensive use of the $1600 \mathrm{sqm}$ site. The new fire protection standard in Switzerland, introduced in January 2005, permits the construction of timber buildings of up to six storeys with a 60-minute fire-resistance capability. Each floor accommodates two spacious apartments of $149 \mathrm{sqm}$ and $166 \mathrm{sqm}$. Cedar woods, anthracite coloured windows, fibre cement cladding (produced by Eternit) and corrugated sheet panels on the balconies characterize the building's appearance (see Figure 10). The basement and ground floors are in concrete construction. From the first floor onwards only the central core, consisting of the staircase and the lift, are made from reinforced concrete, while the walls are in CLT construction and the ceilings are acoustically decoupled, beamed constructions. The timber-metal windows feature triple glazing. The comfort ventilation system, with waste-heat recovery, reduces heat loss through ventilation: subject to correct use by the inhabitants, an effective heat requirement ratio of just $20 \mathrm{kWh}$ per square metre is achievable [51]. A heat pump, with a geothermal probe, supports the heating and domestic warm water systems. Fine tuning of individual measures meant that the development was able to surpass the high criteria demanded by the stringent Swiss 'Minergie' standard. 


\subsection{CLT Building 8: The Forté Apartment Tower in Melbourne Docklands, Australia}

Forté, the 10-storey timber residential building in Melbourne's Docklands, is Australia's first large CLT building and a landmark project for the whole timber industry in Australasia. 9 storeys in CLT sit on top of a concrete podium. The ground floor is used for retail space. The developer is Lend Lease, and its Australian CEO, Mark Menhinnitt, anticipates that 'in future 30 to 50 per cent of their residential projects in the pipeline could be executed in CLT'; he noted 'this project will unlock a new era for sustainable development by offering a viable alternative to traditional construction options, which are carbon intensive' [62]. He expects CLT construction to be used in other applications, including educational, community and commercial buildings.

The advantages of CLT are particularly relevant to the Docklands location and the Victoria Harbour precinct, as its reduced weight generated substantial below-ground savings and the fast build suited the compact site. Forté aims to be Australia's first five-star GreenStar as-built certified residential building. According to the developers, by using CLT, Forté will reduce carbon emissions by more than 1400 tonnes of $\mathrm{CO}_{2}$, compared with building in concrete and steel. The advantages are likely to continue for residents too: the 23 apartments require 25 per cent less energy to heat and cool than a similar apartment built in reinforced concrete; they note that the building will be carbon neutral for at least 10 years.

Construction of the building took only from February to October 2012, constructed from 760 CLT panels, which were shipped from Austria to Australia in 25 containers (panel length limited to 12 metres due to container size). In the assembly process, around 25 panels per day were put in place. However, only few timber surface is exposed in the final building, reduced to one 'feature wall' per unit. An earlier design option proposed the entire building to be wood clad, but 'it was then decided to reduce the timber aesthetic, to avoid marketing risks' [62]. The developer decided on 'a more ordinary façade to have a building not completely out of the ordinary.' The developer also decided that 'the building would be fully sprinklered to make it look safe and simplify the approval process, although this measure was not requested by the Fire Department' [62]. (See Figures $11 \mathrm{a}$ and b).

Figure 11. (a) The 10-storey 'Forté' apartment building in Bourke Street, Melbourne Docklands, under construction (2012); (b) 760 CLT panels stored in a warehouse close to the site. Timber is ideal for prefabrication.

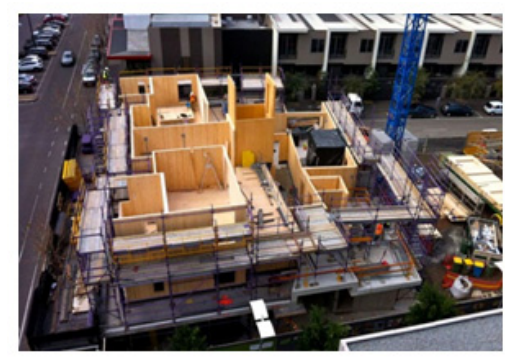

(a)

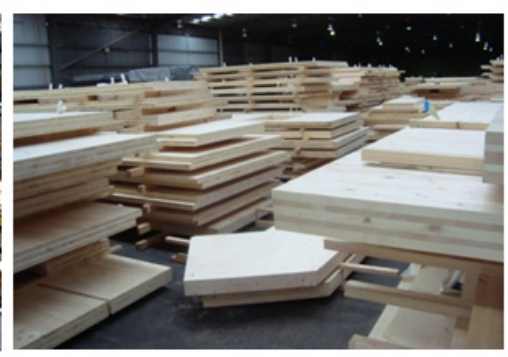

(b) 


\section{What Architects and Developers Think About CLT Construction}

There is still a lack of knowledge within the architectural design community about CLT buildings' design and the impact of various design features on infill developments' carbon footprints - as compared to other construction systems. In Australia we need to find ways to increase acceptance and build industry capacity for rapid uptake of CLT construction systems.

A fundamental question is the potential market penetration and architects' and developers' acceptance of urban infill using CLT construction. The analysed cases show that not only technological but also social innovation is needed to introduce CLT systems more widely to Australia.

Since the mid-1990s, CLT construction has been introduced in several European countries and also in Canada. In Canada, CLT was used as a demonstration in the iHouse constructed for the 2010 Winter Olympics and has successfully been used in hybrid structures such as in the Earth Sciences Building at the University of British Columbia. The recent CLT introduction in Canada indicates that 'a market penetration rate of up to 15 per cent in 5 to 7 years is realistic' [63].

In Europe, engineered timber has become a growing sector: a recent European industry report, summarized in an article in Holzkurier [64], describes the realities of the CLT trend by highlighting that the top 16 producers of CLT panel systems were operating at 120 per cent of capacity in 2009-10 and were projecting a 20 per cent growth in production in 2010-11. The article notes that total production volume of CLT panels reported for 2009 was 269,500 cubic meters. Projections for 2012 (including new producers and new plants in the Czech Republic, Italy and Austria) would exceed 520,000 cubic meters. While there is a CLT construction boom emerging in middle Europe, CLT is still not a fully accepted system in many of the Scandinavian countries, despite their abundance of forests. The research will need to explore the hindrances that are evident in the Nordic countries, where engineered timber still has a small share of the market.

Research has been conducted in the assumed barriers. Roos et al. [65] commented that architects are primarily responsible for producing a functional design that should also be aesthetically pleasing to the client. They saw developers, on the other hand, as risk-averse in their planned constructions, and they select materials in a cost-constrained context.

Discussions with architects and developers during the scoping study conducted by Lehmann and Hamilton revealed significant interest in the CLT product in Australia, where both architects and developers were keen to compare the designs of a CLT building with that using traditional concrete and steel construction system. The use of Building Information Modelling (BIM) and Precinct Information Modelling (PIM) software for design of buildings and neighbourhoods is becoming more widespread, and architects who were interested in CLT were also keen to work with structural engineers to increase their knowledge of alternative low-carbon construction systems. BIM is already changing the nature of the procurement and delivery process of buildings. It will be interesting to see how development of new modelling software will support this trend. Prefabrication, driven by the latest CAD-CAM technology, allows the production of complex projects with many different individual elements, each designated for a certain position in the building.

Architects and developers frequently raised concerns regarding durability and acoustics, for example in regard to the maintenance required to keep the timber looking 'clean'. Sharing knowledge will be essential both through international research collaborations on CLT in Australia and by 
drawing on the European experience. Technical concerns include a focus on the structure and stability of CLT buildings, seismic design, durability design, adhesives, acoustics and vibrations, fire design and energy efficiency.

For industry acceptance of CLT construction, cultural, organizational and policy changes need to occur first, before new technologies can be introduced; including, for instance, policy changes (based on fire testing) to building and planning legislation throughout Australia [66]. Regulatory changes are required to achieve this innovation, as well as stakeholder engagement, itself dependent on behaviour change. Such cultural shift is essential to achieve better project outcomes, and it will be critical for the continuous development and improvement of organizations. Similarly, social acceptance plays a vital role in the implementation of any technology innovations [67].

While technology marches on, regulations and building codes lag behind. British Columbia in Canada recently revamped its building codes to allow taller buildings to be made from wood, but still capped their height at a modest six storeys (in comparison, the UK, Norway and New Zealand place no height restrictions on safely-made wooden high-rise).

The barriers and opportunities identified by the architects and developers are summarized in the following Table 2, while Figure 12 lists the attitudes in material specifications.

Table 2. Stakeholder issues: property developers and architects [45].

\begin{tabular}{|c|c|c|}
\hline Motivation & Barriers identified & Opportunities identified \\
\hline $\begin{array}{l}\text { Stimulate property } \\
\text { development market in } \\
\text { Australia } \\
\text { Gain approval for car } \\
\text { park top developments } \\
\text { Address construction } \\
\text { waste } \\
\text { Adopt innovation } \\
\text { Want to use CLT in } \\
\text { regional project } \\
\text { Want advantage of being } \\
\text { first to design with CLT } \\
\text { Want to gain experience } \\
\text { in designing with CLT } \\
\text { Seeking knowledge } \\
\text { Share knowledge about } \\
\text { feasibility, affordability }\end{array}$ & $\begin{array}{l}\text { Developers and builders unfamiliar with CLT } \\
\text { product } \\
\text { No CLT manufactured in Australia - need to } \\
\text { import CLT panels from overseas } \\
\text { Infill development solutions needed in inner- } \\
\text { city location } \\
\text { Financing of CLT projects through the banking } \\
\text { sector is unclear } \\
\text { CLT not 'affordable, social housing' material } \\
\text { Public education lacking; user acceptance? } \\
\text { Fire engineering and meeting fire regulatory } \\
\text { approvals } \\
\text { Cost of fire testing } \\
\text { Developer confidence in gaining approvals- } \\
\text { no-one wants to pioneer CLT } \\
\text { Improve durability in terms of weather, fungal } \\
\text { and termite resistance } \\
\text { Need to train industry (up-skilling). Concern } \\
\text { about number and size of projects }\end{array}$ & $\begin{array}{l}\text { Government assistance to develop } \\
\text { car park sites } \\
\text { Locate infill development in } \\
\text { centres, infrastructure to service } \\
\text { growth } \\
\text { Timber houses: public still needs } \\
\text { to be educated that it's better than } \\
\text { brick or concrete } \\
\text { Needs to be pitched as a high-end } \\
\text { market product } \\
\text { Manufacture-import from China } \\
\text { or Vietnam to reduce cost? } \\
\text { Undertake comparison of design } \\
\text { in CLT with steel or concrete } \\
\text { systems-LCA } \\
\text { Use design for fire testing } \\
\text { research } \\
\text { Need to address cost and } \\
\text { affordability as part of } \\
\text { sustainability }\end{array}$ \\
\hline
\end{tabular}


Figure 12. Diagram on power and attitude in the process of material selection. (Adapted from: Roos et al., [65]).

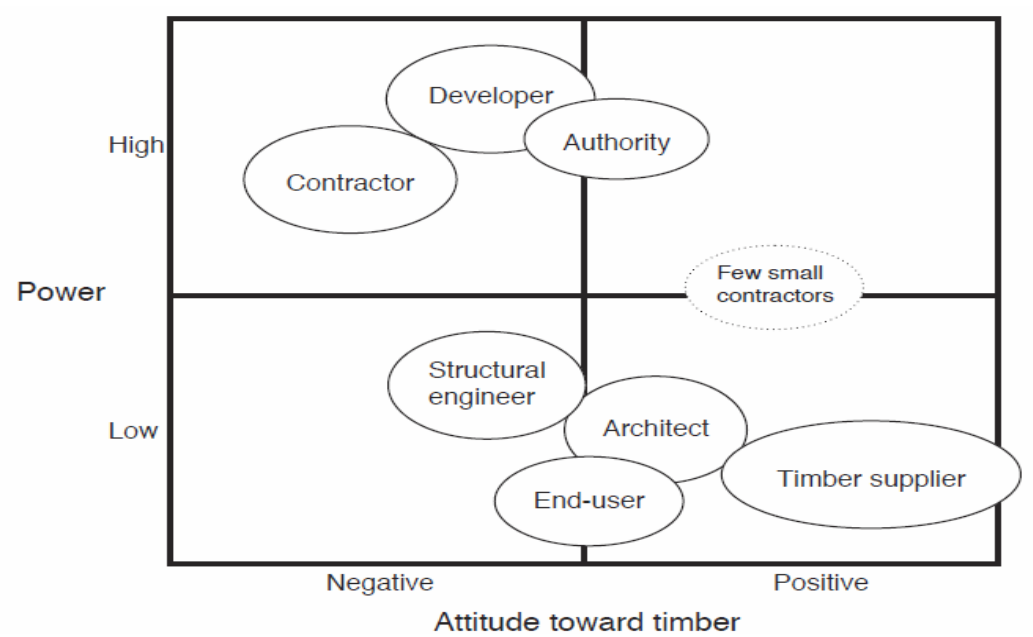

\section{Consumers and Residents: Mobilizing Behaviour Change to Build Liveable and Sustainable Cities}

Users' expectations and needs frequently focus on useability, affordability, comfort, cultural values and aspirational status goals, while the technical solution or construction system itself is less important to residents. Hence, the shift to infill buildings constructed in CLT requires behaviour change, to ensure these buildings will be acceptable to occupants as an alternative approach based on ideas of environmental construction (such as, for instance, new 'passive house' standards being slowly embraced by consumers).

We must understand that people do not necessarily make decisions in a logical way. Instead, behaviour is frequently governed by instinct, emotion, status, past events, current socio-cultural beliefs and values, and one's peer or social group. Changing the behaviour of housing consumers will require significant insight or inspiration, a threat or an event that makes them think and re-evaluate actions or beliefs, thus initiating the process of change.

That buyers of apartments are really prepared to pay more for apartments in environmentally friendly buildings has been disputed for a long time. Architect Michael Green, for instance, notes: ' 95 per cent of the public tell us they would pay more because the building is green; but only 5 per cent really do' [68].

Houses made of wood are, of course, nothing new to Australians. The 'Queenslander' house is a prefabricated timber house that can be dismantled and reassembled on other sites; and older style houses in Perth, for instance, are made of wood and are frequently plagued by termites and fire; they are less durable than brick structures and tend to have a lower resale value, all else being equal. So understandingly there is some scepticism about wooden apartment buildings.

But the successful introduction of CLT construction systems in Europe provides powerful evidence of the efforts needed where industry is entrenched in 'old ways' of doing business and resists a new mindset: the introduction of a more sustainable procurement pathway that includes a sustainable source of raw material (re-growing timber) and sustainable manufacturing principles. 
While CLT timber multi-apartment buildings do not currently conform to fire norms or to established notions of lifestyle, they challenge our stereotypes of 'living in a timber box' and it is likely that fire testing will soon remove regulatory barriers. Many forms of new architecture were initially challenging and ground-breaking, questioning cultural values and traditional understandings; but have subsequently been accepted and embraced by users [69,70]. It is therefore essential to encourage new ideas about lifestyle that break with conventions (for instance, questioning the out-dated 'Australian dream' of living in a suburban one-storey house), that test preconceptions and, potentially, reframe our notions of urban lifestyle and post-industrial conditions [3]. Then we can shift values and attitudes towards inner-city living in apartments.

Customer readiness for change and the perceived ease of use and usefulness of the new building material represent important steps towards the much needed social acceptance of CLT as an ideal building material to increase the density of Australian cities. Behavioural change requires a positive attitude towards CLT. Rewards for embracing CLT will support the uptake of this new building material, while showcasing CLT's capabilities in demonstration buildings will further enhance the uptake. For instance, signage outside the pilot projects could show how many resources were saved and the $\mathrm{CO}_{2}$ emissions and tonnage of waste avoided by each building [71].

\section{Swapping Backyards for Balconies: A Methodology for Further Research, Including Acceptability and Desirability}

This ongoing research is work in progress and findings are still speculative. Two problems require focus: firstly, models of urban infill; then the study of how the use of the CLT systems can play an important role in achieving a more livable city with better models of infill housing (CLT as a sustainable construction system for urban infill). Both problems are relevant and intertwined.

Further research is required to better understand both the social acceptance of CLT multi-storey apartment living in urban centres; e.g., what triggers people to choose a more urban lifestyle by moving back to the city centre, into timber high-rise. Researchers at the Zero Waste Centre for Sustainable Design and Behaviour $(\mathrm{sd}+\mathrm{b})$ are planning two research projects to increase the knowledge base required to introduce CLT construction systems into the Australian building/construction and development sectors. The first (Project 'CLT 1') relates to developing acceptable solutions for regulatory approval of CLT buildings and addresses the technical barriers required to ensure a safe, acceptable product for urban infill development, including the obvious question of fire safety. The fire performance of CLT panels and timber high-rise buildings has been subject to extensive testing and detailed evaluation over the last decade; e.g., the measured burning speed of CLT panels is around $0.6 \mathrm{~mm}$ per minute [34,72-74].

The second area of research (Project 'CLT 2') is still in development and is likely to explore further the sustainability of CLT buildings, focusing on occupier acceptance for infill development in Australian cities and industry supply chains' capacity to sustainably satisfy demand to 2030. The proposed research methodology will include the Delphi Approach, which aims to obtain consensus amongst a group of experts on issues where subjective opinion must be resolved (but opinions differ), by identifying group opinion as more valid than individual opinion. 
In the coming year, the Centre plans to conduct a comprehensive analysis and post-occupancy evaluation of all eight case studies, in close consultation with the developers and government agencies responsible for the housing developments. It will consist of questionnaires completed by the residents to determine the performance of the timber housing as described by a matrix of indicators, including: operational energy and water consumption, affordability, environmental sustainability, and social sustainability factors such as desirability, adaptability and social acceptability. Results will subsequently be published in papers and a book publication. The process will shift the focus from simple questions of technical efficiency to the behaviours and attitudes of the occupants of the selected CLT buildings, transforming their household consumption and current housing management practices into quantifiable evidence. We will compare the POE results with the aims of the case studies to inform subsequent CLT housing developments. We will also consider perceptions of the social status of residents in CLT housing projects by others in the neighbourhood and include provision for suggestions from the residents for improvements in this regard.

The aim of this research is to develop a comprehensive model of Australian CLT housing construction that offers effective guidance for the future delivery of affordable and sustainable housing by considering the needs and expectations of future consumers, the perspective of housing providers, and the structural challenges presented by the requirement to improve affordability and sustainability. The next step is the POE which, in addition to in-depth analysis of the selected cases, will include a mapping exercise comparing the concept with the experiential reality. The resulting comprehensive indicator matrix will enable us to develop a rigorous model on which Australian CLT initiatives can be based. For instance, answers need to be explored to the following questions:

- What are the barriers to sustainable housing transition?

- What are the motives and roles of the architects, real estate agents and engineers involved?

- How strong was the public engagement with these CLT projects?

Finally, understanding the barriers to change and policy levers for accelerating innovation, this research will explore the liveability/acceptability of CLT buildings for infill development in Australian conditions and climate, taking the knowledge developed in Project 'CLT 1' and assessing the expectations and experiences of occupants through occupancy satisfaction surveys (post-occupancy evaluation research has not yet been conducted).

\section{Conclusion and Further Discussion}

The most urgent areas of action for planners and engineers that have emerged are probably in the fields of:

- Renewable energy;

- Water and waste in the built environment;

- Electric vehicle mobility and green infrastructure;

- Eco-city planning and green space linked to a public health agenda;

- Low carbon construction systems;

- Inner-city housing models attracting people to move back to the centre. 
Better housing design can significantly improve health outcomes. The integration of affordability and sustainability in housing is of crucial importance for the future development and re-development of Australian urban areas. The author found that the barriers and obstacles are not so much technical as human. This is why we have to raise low-carbon construction systems to the top of our research agenda and focus attention on transforming industry to enable long-term change. In Australia, solid wood panel construction has to be moved beyond being a niche innovation that is only carried out by a small network of pioneers.

This paper has focused on cross-laminated timber as the most promising of a range of engineered timber technologies. There is now a sense of momentum behind CLT that will hopefully flow through to other engineered timber building systems and composite possibilities. Many of the new engineered timber buildings are hybrid constructions. The e3 Building in Berlin uses a combination of CLT panels, glulam elements and 'Brettstapel'; the Earth Sciences Building in Vancouver uses an OSB-type laminate in its floor panels as composite with a concrete topping; the Massey University building and LifeCycle Tower in Dornbirn use panels with laminated timber webs and concrete toppings.

Since 2005, various high profile landmark buildings have been realised in CLT technology and the construction system is now getting more and more established in Europe, the UK and Canada. The construction sector's focus on embodied energy and carbon storage has increased recently.

Wood is a rapidly renewable resource. Currently, CLT structural timber is made from wood of the managed pine forests of northern Europe and Scandinavia. But, as global carbon will become an important commodity, it could be likely that China will start planting mega-forests on a scale the world has never seen.

Technology itself is not the main problem identified; the main barriers are the slow uptake by industry and consumer resistance to denser inner-city living and new construction materials/systems. For instance, further research is needed to analyse whether residents are more likely to accept higher densities when they know that the density is caused by very green buildings? It is essential to consult the community, for example in neighbourhoods earmarked for higher density and major developments. Studies of international 'successful' cities have shown that those that enjoy broad community support for their city's policies have both consulted and developed consistent plans over time. The recent report by the Grattan Institute Cities: Who Decides (2010) [75] found that encouraging the community to meaningfully participate in the decisions that governments make about the city is fundamental in developing plans that are embraced and supported by the community. This includes the development of thoroughly researched alternative scenarios that are canvassed publicly: articulating a new Australian dream for the 21st Century, to succeed with urban infill projects proposing higher densities and multi-storey timber construction. It is about a sustainable approach to accommodating population growth in cities, while also recognizing the need for additional research on the user viewpoint. The general problem of Australians' historic resistance to apartment living (which has much to do with the apartments' poor design, small size, tall shape, noise and high cost), and the lack of experience with infill sites in Australian cities, mean we will need to learn how to do infill better and gain more knowledge in this area.

The case studies reviewed make a strong argument for timber in the urban context. But the cases also show that there is still a need to instill confidence in the performance of solid wood panel buildings as designed, so that they will be accepted in Australia, by professionals required to certify 
construction to the country's standards and by the market. From the perspective of residents, social acceptance of CLT buildings will be influenced by factors affecting liveability, comfort and the consequent socio-economic outcomes. For example, we still lack knowledge about the public perception of CLT buildings for infill development in Australia and their performance in all conditions, including heat waves. Another question is: how far do income, education and age of residents play a role in the level of acceptance and awareness of green construction methods using CLT panels?

Both the general public and the architectural community lack knowledge about the design of CLT buildings and the impact of various design features on the carbon footprint of their use for infill development compared to other modern methods of construction. Education of architects and planners is everywhere lagging behind. Educators should be developing new courses that focus on research methods into new materials and low carbon construction systems, aiming to reposition future architects as more knowledgeable (and again, as influential) in the construction industry.

The author recommends that government agencies and the building industry could be involved throughout this ongoing research, as this will lead to an increased understanding and knowledge of the properties of CLT buildings and inform favourable decisions that encourage their use for infill development. The research will have to be tested on actual affordable and sustainable housing developments, delivering demonstration pilot projects.

It is important that solid wood panel construction should not simply be a hidden substitute for concrete or steel, but needs to express a 'new wooden architecture'. Timber could be more visible and express more freely a new aesthetic (rather than being hidden beneath cladding). It's likely that future large timber constructions are hybrid buildings: timber in combination with some concrete (as prefabricated composite concrete-wood slabs), but without the complicated steel joints.

In conclusion, the author has identified the following actions that government and industry could pursue:

- Modify building codes to make sustainable building practice and urban infill the norm, zoning out car-dependent greenfield developments on the city fringe.

- Demonstrate the benefits of CLT construction systems by using them to create exemplary housing projects that are affordable and sustainable; working towards the delivery of an iconic demonstration building showcasing the capabilities of the product, and enhancing awareness.

- Use the opinions of committed investors, committing owners and occupants of CLT buildings to promote a positive greening identity change of the city in which they are located.

- Accompany realisation with data monitoring and testing.

- Conduct in-depth research on behaviour change to facilitate and accelerate the move towards more inner-city housing that is fully embraced by residents in Australia.

- Identify the facilitators of and barriers to solid CLT technology transfer with industry, university and government partners internationally and produce a feasibility report for investors identifying the most commercially viable solid timber solution for the determined market with a road map for implementation (e.g. ensure the supply of sufficient wood necessary to deliver prefabricated panellised systems in high quantity). 
- Ensure longevity of the implemented strategy via suitable up-skilling of industry professionals (from architects and engineers to builders) via continuous professional development (CPD) activities.

- Establish the production of a standardized quality assurance process for fabrication, details for construction and the creation of technical specification literature.

- Establish a green supply chain for domestic CLT panel manufacturing; instigating a strategy for the suitable uptake of CLT system fabrication in Australia relative to market requirements, available technology and wood resources.

- Support the Australian design, construction and timber industries in the uptake and adoption of emerging engineered timber technologies.

- Advance evidence-based policy and practices through a user-centred approach to housing occupancy evaluation and effective understanding of feedback.

- Implement zero waste concepts with detailed targets for the construction sector, doing away with construction waste going to landfill.

- Make embodied energy and resource/material efficiency a key focus of government policy, setting minimum standards of efficiency that buildings must meet.

- Encourage all levels of government to take the lead in innovative construction, by leasing CLT high-rise buildings and by implementing a grant scheme for construction of such buildings.

- Produce peer-reviewed published work ensuring market and product confidence including worldwide dissemination of standardized information on engineered timber.

- Publish a technical handbook and associated launch event with a conference on solid cross-laminated timber production and construction (e.g. the technical barrier is not structural, but the high fire requirements).

In this paper the author has assessed the potential contribution of CLT construction to the creation of innovative and long-lasting housing types to increase the urban density of existing cities. This alternative approach is grounded in concepts of both environmental and social responsibility. Since timber is a material that has the capacity to store carbon it offers the opportunity for carbon engineering, to turn buildings into 'carbon sinks'. The negative environmental legacy of conventional 'hard' development and construction could be minimized by using CLT construction on brownfield sites. Inner-city housing using highly engineered timber construction also offers the opportunity to re-establish more meaningful concepts of material culture and enduring value, thus underpinning a more profound notion of society itself.

There are in any type of restructuring some short-term costs, but there is an impressive array of benefits that can accrue from the transition to low carbon timber construction systems, such as healthier living and working conditions. Long-term benefits associated with a transition to a low carbon economy are now becoming clear [76]. It's time to grab the considerable opportunities that are opening up in front of us. Supported by the rapid developments in CNC-technology, prefabricated engineered solid wood panel systems are now a cost competitive technology for 3 to 10 storeys residential structures, replacing concrete and steel construction, reducing ecological footprint, and delivering healthy indoor environments of future buildings. 
One conclusion that can already be drawn from the cases is that issues around the adoption of CLT in residential construction are worthwhile of further detailed study. The interrelated mix of technological and social considerations required will provide a mature perspective on the complexities of influencing behaviour change in this domain.

The expected research findings are likely to also provide insight in the question of how far the consumer factors are relevant to moving towards increased use of CLT for buildings, or if the barriers are really about values towards the environment at all; or are they rather to some extent down to unfamiliarity and inertia? Equally, it is important to consider behaviour change as something required of the building industry, local planners, and so on, as well as from householders.

Finally, using solid wood panel systems on an urban scale will mean faster, lighter, better performing and more flexible buildings in the city. It looks like timber, the traditional construction material of the past, will become the construction material for the future.

\section{Acknowledgements}

This paper draws on the work of the author at the Zero Waste Centre for Sustainable Design and Behaviour ( $\mathrm{sd}+\mathrm{b}$ Centre), at the University of South Australia, and the UNESCO Chair in Sustainable Urban Development for Asia and the Pacific. The author is grateful to colleagues who provided comments on earlier drafts and to reviewers for their constructive suggestions that have improved this paper.

\section{Conflict of Interest}

The author declares no conflict of interest.

\section{References}

1. Girardet, H. The Metabolism of Cities. In The Sustainable Urban Development Reader; Wheeler, S., Beatley, T., Eds.; Routledge: London, UK, 2004.

2. Urban Energy Transition: From Fossil Fuels to Renewable Power; Droege, P., Ed.; Elsevier: Oxford, UK, 2008.

3. Lehmann, S. The Principles of Green Urbanism: Transforming the City for Sustainability; Earthscan: London, UK, 2010.

4. Schiller, P.; Bruun, E.; Kenworthy, J. An Introduction to Sustainable Transportation: Policy, Planning and Implementation; Earthscan: London, UK, 2010.

5. West, G. The surprising math of cities and corporations, TED talk by Geoffrey West, 2011. Available online: www.youtube.com/watch?v=XyCY6mjWOPc (accessed on 3 March 2012).

6. Green Building Council Australia (GBCA). Building a Sustainable Future. Putting a Price on Pollution: What it Means for Australia's Property and Construction Industry. Available online: www.gbca.org.au/uploads/203/3787/Carbon\%20Paper_LR.pdf_(accessed on 3 March 2012).

7. Meadows, D.H.; Meadows, D.L.; Rander, J.; Behrens, W.W. Limits to Growth: A Report for the Club of Rome; Potomac: New York, NY, USA, 1972. 
8. McKinsey and Company. An Australian Cost Curve for Greenhouse Gas Reduction; McKinsey: Sydney, Australia, 2008.

9. Walker, S. Sustainable by Design: Explorations in Theory and Practice; Earthscan: London, UK, 2006.

10. Brown, L.R. Plan B 4.0 Mobilizing to Save Civilization; Norton: New York, NY, USA, 2009.

11. FWPA Forest and Wood Products Australia. A Review and Update of Emerging Technologies in Residential Timber Constructions; Report; FWPA Forest and Wood Products Australia: Sydney, Australia, 2012. Available online: www.fwpa.com.au (accessed on 3 September 2012).

12. Guerra, E.; Cervero, R. Transit and the 'D' word. Access, No. 40, Spring 2012; University of California Transportation Center: Los Angeles, USA; pp. 2-8.

13. Commonwealth of Australia. State of Australian Cities; Report; Infrastructure Australia, Major Cities Unit: Canberra, Australia, 2010.

14. Government of South Australia. The 30-Year Plan for Greater Adelaide: A Volume of the South Australian Planning Strategy; Report; Department of Planning and Local Government: Adelaide, Australia, 2010.

15. Hawken, P.; Lovins, A.; Lovins, H. Natural Capitalism: Creating the Next Industrial Revolution; Little, Brown and Company: Boston, USA, 2000.

16. Garnaut, R. The Garnaut Climate Change Review; Commonwealth of Australia: Canberra, Australia, 2008.

17. Gilding, P. The Great Disruption; Bloomsbury Press: New York, NY, USA, 2011.

18. Grattan Institute. The Housing We Would Choose. Grattan Institute, Melbourne, 2011. Available online: www.grattan.edu.au (accessed on 20 December 2011).

19. Rickwood, P.; Glazebrook, G.; Searle, G. Urban structure and energy: A review. Urban Policy Res. 2008, 26, 57-81.

20. Maliene, V.; Malys, N. High-quality housing: A key issue in delivering sustainable communities. Build. Environ. 2009, 44, 426-430.

21. Winston, N. Regeneration for sustainable communities? Barriers to implementing sustainable housing in urban areas. Sustain. Dev. 2009, doi:10.1002/sd.399.

22. National Housing Supply Council (NHSC). Annual Report 2010-2011; NHSC: Canberra, Australia, 2011.

23. Demographia. 7th Annual Demographia International Housing Affordability Survey 2011. Available online: www.demographia.com/dhi.pdf (accessed on 25 July 2011).

24. Mumford, L. The City in History: Its Origins, Its Transformations, and Its Prospects; Harvest Books Harcourt: New York, NY, USA, 1961.

25. Lyle, J.T. Regenerative Design for Sustainable Development; Wiley: New York, NY, USA, 1994.

26. Brown, L.R. Building a Sustainable Society; Worldwatch Institute/Norton: New York, NY, USA, 1981.

27. Council of Australian Governments (COAG). National Strategy on Energy Efficiency, Annual Report 2010-2011. Available online: http://www.coag.gov.au/reports/index.cfm\#energeff (accessed on 25 April 2012). 
28. McKenzie-Mohr, D.; Nemiroff, L.S.; Beers, L.; Desmarais, S. Determinants of responsible environmental behavior. J. Soc. Issues. 1995, 51, 139-156.

29. Urban Consumption; Newton, P., Ed.; CSIRO Publishing: Melbourne, Australia, 2011.

30. Designing for Zero Waste: Consumption, Technologies and the Built Environment; Lehmann, S., Crocker, R., Eds.; Earthscan/Routledge: London, UK, 2012.

31. Kaufmann, H. Wood Works: Ökorationale Baukunst-Architecture Durable; Springer: Berlin, Germany, 2011.

32. Lippke, B.; Oneil, E.; Harrison, R.; Skog, K.; Gustavsson, L.; Sathre, R. Wood products reduce carbon dioxide emission levels. Carbon Management 2011, 3, 303-333.

33. Vessby, J.; Enquist, B.; Petersson, H.; Alsmarker, T. Experimental study of cross-laminated timber wall panels. Eur. J. Wood Prod. 2009, 67, 211-218.

34. Frangi, A.; Fontana, M.; Hugi, E.; Joebstl, R. Experimental analysis of cross-laminated timber panels in fire. Fire Safety J. 2009, 44, 1078-1087.

35. Gereke, T.; Gustafsson, P.J.; Persson, K.; Niemz, P. The hygroscopic warping of cross-laminated timber. In Delamination in Wood, Wood Products and Wood-Based Composites; Bucur, V., Ed.; Springer: Heidelberg, Germany, 2011.

36. Friedley, K.J. Wood and Wood Based Materials Current Status and Future of Technical Material; American Society of Civil Engineers: Reston, VA, USA, 2002.

37. Department of Primary Industries of New South Wales (DPI NSW). Why Wood Products Should Be Used More; Department of Primary Industries: Sydney, Australia, 2006. Available online: www.dpi.nsw.gov.au/research/updates/issues/june-2006/wood-products (accessed on 3 March 2012).

38. John, S.; Nebel, B.; Perez, N.; Buchanan, A. Environmental Impacts of Multi-Storey Buildings Using Different Construction Materials; Research Report 2008-02; New Zealand Ministry of Agriculture and Forestry: Christchurch, New Zealand, 2009.

39. Built Environment Industry Innovation Council (BEIIC). Built Environment Industry Innovation Council Recommendations Report, Commonwealth of Australia. Available online: www.innovation.gov.au/industry/BuildingandConstruction/BEIICRecommendationsReport2010. pdf (accessed on 25 July 2011).

40. Wegener, G.; Pahler, A.; Tratzmiller, M. Bauen mit Holz = Aktiver Klimaschutz. Ein Leitfaden; Holzforschung Muenchen: Munich, Germany, 2010.

41. Timber Development Association of Australia (TDA). Australian Timber Database. Available online: www.timber.net.au (accessed on 3 March 2012).

42. Sathre, R.; Gustavsson, L. Using wood products to mitigate climate change: External costs and structural change. Applied Energy 2009, 86, 251-257.

43. WoodWisdom-Net. Networking and Integration of National Programmes in the Area of Wood Material Science and Engineering in the Forest-Based Value Chains. Report by the EU-funded timber research group. Available online: www.woodwisdom.net/ (accessed on 3 March 2012).

44. Lehmann, S. Developing a Prefabricated Low-Carbon Construction System using Timber for Multi-Storey Inner-City Housing. In Creating Sustainable Communities in a Changing World; Daniels, C., Roetman, P., Eds.; Crawford House Publishing: Adelaide, Australia, 2011. 
45. Lehmann, S.; Hamilton, C. Sustainable Infill Development using Low Carbon CLT Prefabrication: Adaptation for the South Australian Context; Zero Waste SA Research Centre for Sustainable Design and Behaviour: University of South Australia, Adelaide, Australia, 2011.

46. Waugh, A.; Thistleton, A. Murray Grove: The World's Tallest Modern Timber Residential Building. Available online: www.waughthistleton.com/project.php?name=murray\&img=1 (accessed on 3 March 2012).

47. Östman, B.; Källsner, B. National Building Regulations in Relation to Multi-Storey Wooden Buildings in Europe; Report; SP Trätek and Växjö University: Växjö, Sweden, 2011.

48. Pons, O.; Wadel, G. Environmental impacts of prefabricated school buildings in Catalonia. Habitant Int. 2011, 35, 553-563.

49. Pullen, S.; Zillante, G.; Arman, M.; Wilson, L.; Zuo, J.; Chileshe, N. Ecocents Living: Affordable and Sustainable Housing for South Australia; Report; University of South Australia: Adelaide, Australia, 2009.

50. Stevenson, F.; Leaman, A. Evaluating housing performance in relation to human behaviour: New challenges. Build. Res. Inf. 2010, 38, 437-441.

51. Lattke, F.; Lehmann, S. Multi-storey timber constructions: Recent trends. J. Green Building 2007, 2, 119-130.

52. Kaufmann, H. Wood Works: Ökorationale Baukunst-Architecture Durable; Springer: Berlin, Germany, 2011.

53. Wells, M. Tall timber buildings: Applications of solid timber construction in multi-storey buildings. CTBUH 2011, 1, 24-26.

54. Ward, R. Going to new heights. Building the world's tallest mixed-use wood structure. Structure Magazine, August 2009. Available online: http://www.structuremag.org/article.aspx ?articleID=947 (accessed on 3 March 2012).

55. Waugh, A. Bigger, taller, better. PowerPoint presentation. In Touch with Timber Conference 2010, London, UK, 18 May 2010.

56. Powney, S. Another CLT star is born: More cross-laminated timber on the London skyline. Timber and Sustainable Building Magazine, 18 September 2011.

57. Fourth Door. Svartlamoen. Available online: http://www.fourthdoor.org/annular/wpcontent/uploads/2010/05/Svartlamoen-bkhousing002.jpg (accessed on 3 March 2012).

58. Building with Timber: Paths into the Future; Kaufmann, H., Nerdinger, W., Eds.; Prestel: Munich, Germany, 2011.

59. Brinkmann, U. In einer Minute gewachsen. In Holzbau fuer die Stadt. Bauwelt, No 21/12, Berlin, Germany, May 2012; pp. 20-30.

60. Winter, W. TU-Vienna, Vienna, Austria. Personal communication, 27 April 2012.

61. Ballhausen, N. Den Holzbau radikalisieren. In Holzbau fuer die Stadt. Bauwelt, No 21/12, Berlin, Germany, May 2012; pp. 35-41.

62. Hopkins, P. Timber challenges steel as the new apartment building stock. The Sydney Morning Herald, Sydney, Australia, 16 July 2012.

63. FPInnovations. Cross-Laminated Timber; FPInnovations Handbook: Québec, Canada, 2011. 
64. Holzkurier. Brettsperrholz Special. Holzkurier. No. 48, 2 December 2010, pp. 13-14. Available online: www.mmkaufmann.com/fileadmin/ablage/dokumente/dokumente/news/HK48_2010.pdf (accessed on 10 September 2012).

65. Roos, A.; Woxblom, L.; McCluskey, D. The influence of architects and structural engineers on timber in construction: Perceptions and roles. Silva Fennica 2010, 44, 871-884.

66. England, P.; Zillante, G. Evaluating the Performance of Buildings Exposed to Bushfire Attack. In Proceedings of the 4th International Conference, Australian Institute of Building Surveyors, Adelaide, Australia, 12-13 May 2007.

67. Yuan, X.; L.; Zuo, J.; Ma, C.Y. Social acceptance of solar energy technologies in China: End users perspective. Energ. Policy, 2011, 39, 31031-31036.

68. Green, M.; Karsh, J.E. The Case for Tall Wood Buildings; MGB Architecture + Design: Vancouver, Canada, 2012.

69. Lilley, D. Design for sustainable behaviour: Strategies and perception. Design. Stud. 2009, 30, 704-720.

70. Daley, J.; Edis, T.; Reichl, J. Learning the Hard Way: Australian Policies to Reduce Carbon Emissions; Report; Grattan Institute. Melbourne, Australia, 2011.

71. Woodsolutions. New ECO2 Module. Available online: www.woodsolutions.com.au/Blog/ AccuRate-ECO2-module (accessed on 3 March 2012).

72. Dehne, M.; Krueger, U. Fire Protection in Multi-Story Timber Construction; Detail, no. 10/2006; Institut fuer internationale Architektur-Dokumentation: Munich, Germany, 2006; pp. 1142-1144.

73. Bootle, K.R. Wood in Australia, 2nd ed.; McGraw-Hill: Sydney, Australia, 2006.

74. Finch, G.; Ricketts, D.; Wand, J.; Thivierge, C.; Morris, T. Enclosure. In CLT Handbook: Cross-Laminated Timber; Gagnon, S., Pirvu, C., Eds.; FPInnovations: Québec, Canada, 2011.

75. Grattan Institute. Cities: Who Decides. Grattan Institute, Melbourne. Avaiable online: www.grattan.edu.au (accessed on 20 December 2011).

76. Environment Protection and Heritage Council (EPHC) and Department of Environment, Water, Heritage and the Arts. National Waste Report 2010; Australian Government: Canberra, Australia, 2010. Available online: www.environment.gov.au/wastepolicy/publications/national-wastereport.htm (accessed on 25 July 2011). 


\section{Appendix}

\section{Related Web Sites:}

\begin{tabular}{ll} 
Binderholz Bausysteme & www.binderholz-bausysteme.com \\
Dataholz & www.dataholz.com \\
Dietrich Untertrifaller & www.dietrich.untertrifaller.com \\
dRMM, Alex de Rijke & www.drmm.co.uk \\
Eurban & www.eurban.co.uk \\
Michael Green & www.mgb-architecture.ca \\
Hermann Kaufmann & www.hermann-kaufmann.at \\
Holzforschung Austria & www.holzforschung.at \\
Kaden \& Klingbeil & www.kaden-klingbeil.de \\
KLH & www.klhuk.com \\
Lend Lease & www.lendlease.com \\
Lignum & www.lignum.ch \\
Lignotrend, Germany & www.lignotrend.de \\
Metsae Wood Merk & www.metsawood.de \\
Merz Kley Partner, Austria & www.mkp-bauingenieure.com \\
Proholz & www.proholz.at \\
Renggli Holzbau & www.renggli-haus.ch \\
Hubert Riess & www.archinform.net \\
Scheitlin, Syfrig \& Partner & www.scheitlin-syfrig.ch \\
Schilliger Holz, CH & www.schilliger.ch \\
s_Lab & www.slab.com.au \\
sd+b Centre & www.unisa.edu.au/sustainable-design \\
Sohm Holzbautechnik & www.sohm-holzbau.at \\
Stora Enso Timber & www.storaenso.com/wood-forest \\
Structurlam, Canada & www.structurlam.com \\
Techniker Engineers, London & www.techniker.co.uk \\
Wolfgang Winter, TU Vienna & www.iti.tuwien.ac.at \\
WoodWisdom-Net & www.woodwisdom.net \\
Woodsolutions & www.woodsolutions.com.au \\
\hline &
\end{tabular}

(C) 2012 by the author; licensee MDPI, Basel, Switzerland. This article is an open access article distributed under the terms and conditions of the Creative Commons Attribution license (http://creativecommons.org/licenses/by/3.0/). 